\title{
Pointing the Finger of Blame: News Media Coverage of Popular-- Culture Culpability
}

\author{
Erica Scharrer \\ University of Massachusetts Amherst \\ Lisa M. Weidman \\ Linfield College \\ Kimberly Bissell \\ University of Alabama
}

Follow this and additional works at: https://digitalcommons.linfield.edu/mscmfac_pubs

Part of the Journalism Studies Commons, Mass Communication Commons, and the Television Commons

\section{DigitalCommons@Linfield Citation}

Scharrer, Erica; Weidman, Lisa M.; and Bissell, Kimberly, "Pointing the Finger of Blame: News Media Coverage of Popular-Culture Culpability" (2003). Faculty Publications. Accepted Version. Submission 8. https://digitalcommons.linfield.edu/mscmfac_pubs/8

This Accepted Version is protected by copyright and/or related rights. It is brought to you for free via open access, courtesy of DigitalCommons@Linfield, with permission from the rights-holder(s). Your use of this Accepted Version must comply with the Terms of Use for material posted in DigitalCommons@Linfield, or with other stated terms (such as a Creative Commons license) indicated in the record and/or on the work itself. For more information, or if you have questions about permitted uses, please contact digitalcommons@linfield.edu. 
Pointing the Finger of Blame: News Media Coverage of Popular-Culture Culpability

\author{
By \\ Erica Scharrer \\ (University of Massachusetts Amherst) \\ Lisa M. Weidman \\ (University of Georgia) \\ Kimberly Bissell \\ (University of Alabama)
}




\section{Introduction}

Throughout the twentieth century, certain segments of U.S. society have blamed the products of popular culture for lowering moral standards and inciting "bad" behavior. After World War I, for example, many blamed movies for bringing the "loose morals" of Europe to America, resulting in women taking up smoking and wearing dresses that exposed their calves. In the 1950s, parents worried that doo-wop and rock and roll would provoke sexual promiscuity in their teenage sons and daughters. And in the 1980s, a group of concerned parents known as the PMRC labeled the music of Madonna, Michael Jackson, Motley Crue and others as a "contributing factor" in teen pregnancy and suicide (Sheinfeld, 1986).

In the 1990s popular media products (including movies, recorded music, television talk shows, the Internet, tabloid newspapers, and video games) were blamed, at least in part, for a number of high-profile tragedies. Among these were the car crash that killed Princess Diana, the murder associated with the "Jenny Jones" show, and the shootings at several high schools in the United States, including the massacre at Columbine High School in Littleton, Colorado. In news coverage of these tragedies, the mainstream news media seemed to lead the charge against their popular brethren by unabashedly reporting on, if not initiating, the finger pointing.

This study explores how and why the news media came to assign blame to products of popular culture in coverage of the three recent high-profile 
tragedies mentioned above. We chose these three tragedies because we see them as variations on a theme: well-publicized, wide-reaching events in which a tragedy occurred that involved popular media in some way and in which a large component of the news discourse that followed involved the blaming of popular media for the tragedies. We argue that the ways in which the "elite" news media covered these events were not isolated or unique but rather exemplified widely held assumptions, common practices, and consistent perspectives regarding news, popular media, and audiences. We see the analysis of three cases, rather than only one, as compelling evidence of the universality of the themes we raise. Through case studies based on qualitative content analysis of Englishlanguage newspaper coverage of these three events, we will answer the following questions:

RQ1: How did the evolution of each story -Princess Diana's death, the "Jenny Jones" talk show murder, and the Columbine High School shootings - evolve over time?

RQ2: At what point in news coverage of each story did popular-culture culpability arise, and from what source(s) did the blame originate?

RQ3: In news coverage of each story, how were products of popular culture such as video games, the Internet, the paparazzi and talk shows blamed for each tragedy?

RQ4: How might we explain the news media placing the blame on popular culture? 
After presenting the case studies, we employ several theoretical frameworks to discuss why popular-culture products, and sometimes their producers, were blamed for these tragic events. Our goal is not to exonerate popular-culture products or their producers but to understand how and why they were implicated in news coverage of the tragedies.

\section{$\underline{\text { Review of Literature }}$}

This research topic has the potential to reveal a great deal about the practices - and perhaps even the motivations - of those who create and control the news. Yet little research has been done on the relationship between the "elite" news media and the various forms of "popular" media, those which serve to entertain more than to inform. Analyses of news media blaming popular media products for causing or contributing to high-profile tragedies are rare. Thus, we briefly review the few studies that look specifically at the coverage of these three tragedies by the news media to provide context for the rather novel study at hand. We also provide a brief overview of the history of blame being assigned to popular media by entities other than the news media. Finally, we turn toward more broad theoretical foundations that can be applied to the particular occurrence of assignment of blame by news media to popular media.

News coverage of the three tragedies studied here implicated many types of entertainment media and popular culture, all of which have been the subject of similar criticism and research scrutiny in the past. Exposure to violence in 
recorded music, for instance, has been associated with antisocial and destructive behavior (Wass, Miller, \& Redditt, 1991), as well as sex-role stereotyping and negative attitudes toward women (St. Lawrence \& Joyner, 1991). Yet a direct causal relationship has been elusive because of both the difficulty in extracting influence of song lyrics in complex decision-making processes (American Academy of Pediatrics, 1996) and the notion that up to $30 \%$ of those adolescents listening do not know the lyrics (Greenfield, Bruzzone, Koyamatsu, Satulof, Nixon, Brodie, \& Kingsdale, 1993). The evidence on the topic is sufficient, however, for the American Academy of Pediatrics to make recommendations to parents about "reducing the potential negative effects of music lyrics and videos" (1993, p. 1).

There also exists an extensive history of blaming violent films for encouraging antisocial behavior (e.g., Payne Fund studies; Charters, 1933; Peterson \& Thurstone, 1933), as was the case in news coverage of the shootings at Columbine. Among the more recent contributions to this literature are analyses finding increases in aggression levels after exposure to violent films, often greater for those aggressively inclined prior to exposure (Anderson, 1997; Betsch \& Dickenberger, 1993; Black \& Bevan, 1992). Similarly, a growing body of research links video-game use - raised as a causal factor for the Columbine shootings - with increased aggressive behavior and desensitization toward violence (Anderson \& Ford, 1986; Ballard \& Lineberger, 1999; Ballard \& Wiest, 1996; Irwin \& Gross, 1995; Silvern \& Williamson, 1987). Other research has found 
elevations in aggressive play following violent-video-game use rather than aggressive behavior directed toward others (Cooper \& Mackie, 1986; Schutte, Malouff, Post-Gordon, \& Rodasta, 1988).

Two other aspects of popular culture widely blamed in these cases, particularly the Columbine case, include television violence and extensive news coverage of violent events (because such coverage may lead to copycat behavior). Both have received attention in studies too numerous to identify here, yet Berkowitz (1993), Surette (1997), Comstock and Scharrer (1999), and Potter (1999) provide informative overviews of each.

Analyses of the amount or treatment of violence in newspaper content are surprisingly scant. One exception is Clark and Blankenberg's (1972) study of violence across different types of media that found about $18 \%$ of newspaper front pages featured violence. There is also a growing amount of research on the topic of news coverage of violent events involving youths, an issue relevant to the Columbine tragedy. For example, an analysis of local television news in California found that over half of the nearly 1800 stories analyzed that contained violence featured youths (Dorfman, Woodruff, Chavez, \& Wallack, 1997), similar to the $48 \%$ of violent stories that involved children in an earlier study (Kunkel, 1994). A similar study in California the following year found $68 \%$ of all violent stories involved youths (Dorfman \& Woodruff, 1998).

To our knowledge, no scholarly research has linked daytime television talk shows or tabloid publications - the two remaining objects of blame in these 
cases - to adverse media effects, though these popular forms of communication have certainly been criticized in the news media. One exception is a study by Tavener (2000), who argues that daytime talk shows elicit moral panics among middle-class cultural critics and mainstream journalists but that, in fact, shows such as "Jerry Springer" and "Jenny Jones" serve to reinforce middle-class values and mores. However, a few studies conducted over the last decade have examined the often-controversial content of talk shows. Brinson and Winn (1997) report one reason for the format's popularity has been an increased emphasis on interpersonal conflict. Critics of the "Jerry Springer Show" suggest the show's premise is to spark controversy and conflict in the hopes of elevating the conflict to a physical level, often with violence (Long, 1999). As the trend of revealing "secrets" or disclosing private information in front of a national audience became more popular, a few researchers began to explore the social role of these programs in society and the talk-show guests themselves.

Anderson (1993) and Oliver (1995) suggest that talk shows are "modern, mass mediated freak shows" (p. 94), and critics, ranging from journalists to political figures to a talk-show host (Oprah Winfrey) have charged talk shows with emphasizing sexual themes, sexual practices, and sexual deviance (Greenberg, Sherry, Busselle, Hnilo, \& Smith, 1997). Abt and Seesholtz (1994) found in their analysis of talk-show content that talk shows are dominated by sexuality, themes of deviance and psychopathology, and self-disclosure of private facts. Greenberg and colleagues (1997) found in their analysis of 110 talk- 
show episodes that sexual activity was a major issue of discussion in $36 \%$ of the shows and discussion of criminal acts was a major issue in $24 \%$ of the shows. Brinson and Winn (1997) analyzed representation of interpersonal conflict in 40 randomly selected talk shows and found aggressive behavior in approximately $25 \%$ of the shows.

In another area of talk-show research, Priest and Dominick (1994) examined the relationship between talk-show participants, their exposure to television, and their reasons for choosing to disclose sensitive and private information in a public forum. They found that participants on the "Donahue" show reported a "pragmatic attitude toward talk shows as a forum to reach a number of audiences" (p. 74). Though some talk-show guests were aware that they might face ridicule or embarrassment on the program, they were willing to do so in order to "evangelize" their issue or position. In another investigation of self-disclosure on talk shows, Peck (1995) found that talk-show participants viewed the talk-show stage as an extension to therapy, thereby enabling talkshow participants to perceive their participation on the show as a step in the healing process.

A few studies have looked specifically at news-media coverage of Princess Diana's death. Real (2000) used print and broadcast news coverage of Diana's death and funeral to explicate a theory that the media serve a religious function in modern society. Real did not focus on the "elite" media blaming popular culture for the tragedy, but he suggested that "the intense controversy over the 
possible role of media paparazzi in her death...functioned largely as a displacement attempting to find blame to explain away the unexplainable finality of death" (p. 6). Eichholz (1998) studied the extent to which German and American newspapers (both "elite" and tabloid) criticized tabloid photographers and the tabloid press for their purported role in Diana's death. He found that "on average, elite newspapers devoted $25 \%$ of their coverage to the role the media played, compared with only $5 \%$ the tabloids devoted to the media's role" (p. 13). Eichholz also found "the elite media were more willing to voice media criticism because they aimed most of their critique at the tabloids and the paparazzi, while at the same time differentiating themselves from these groups" (p. 14).

Bishop (1999), whose study is most similar to the study at hand, focused primarily on how the news media (both print and broadcast) actively differentiated themselves from tabloid publications in their coverage of Diana's death. Through textual analysis, Bishop identified a pattern of coverage that served to distinguish "elite" journalists and "elite" media from tabloid-press photographers and tabloid publications. Bishop found that journalists for the "elite" media "struggled to keep their readers and viewers aware that the paparazzi, and British and American tabloids, did not practice journalism with the same level of professionalism" (p. 90).

\section{Theoretical Foundations}

Media Discourse and "Serious" vs. Tabloid Journalism 
In addition to the particular studies cited above, the works of Bird (1992), Jensen (1990), Pauly (1992), and Eason (1992) contribute to our theoretical framework for interpreting the mainstream news media's handling of the three high-profile events studied here. This framework views communication as a symbolic social practice and media content as the negotiated outcome of the social practices of its producers and the public.

Bird (1992) writes about supermarket tabloids as cultural phenomena, existing "alongside and because of other cultural phenomena" rather than merely as disconnected parts (pg. 1). She stresses the importance of considering intertextuality, or the relationship of one media product to other media and oral traditions, when studying the role of a media product (in her case, tabloids) in people's lives. Bird argues that the writer, the reader, and the content itself contribute to "the cultural phenomenon of the tabloid" (pg. 4), and she counters criticism of tabloid journalism by "serious" journalists with evidence of the close connection between "serious" and tabloid journalism, both past and present.

The connections to be made with our study are several. First, we must consider the cultural phenomenon we are examining, the assignment of blame in newspaper journalism to elements of popular media, in context with other cultural phenomena. If popular media are being portrayed in a negative light and the reader is a fan of popular media, a complex intertextual scenario may transpire. How audience members read news coverage that places responsibility 
for social ills on popular media may certainly be mitigated by audience members' own relationships with popular media.

Also relevant to our study is the relationship between "serious" journalism and tabloid journalism. In our study, we expect tabloid journalism will be directly implicated in both the "Jenny Jones" and the Princess Diana cases. This relationship parallels that of the popular media (video/computer games, movies, television shows, recorded music) implicated in the Columbine case. Central to our discussion of the treatment of these entities by journalists employed at major newspapers is the apparent division between the popular and the "elite" being drawn by the "serious" journalists in non-tabloid publications (Bishop, 1999; Eichholz, 1998). We argue that in order to point the finger of blame at media in general but deflect blame from one's own media outlet, this delineation is drawn. Yet, as Bird suggests, the distinction between "serious" and popular media is not one of opposite sides of a polemic but rather blurry points on a continuum.

Jensen (1990) analyzes decades of discourse about ill effects associated with media, although she examines scholarly arguments made by media critics whereas we examine news articles appearing in major newspapers. Jensen argues that when critics rail against the powers and persuasions of media, the underlying assumptions and beliefs they are advancing are fundamentally complaints about modernity or what modern times have wrought. She does not attempt to determine whether there are unfavorable influences of the media on 
society or on individuals but rather she analyzes the discussion or discourse surrounding that topic. We adopt the same stance in our study in that we do not attempt to determine whether the popular media discussed in newspaper coverage of these three events are to blame for the three tragedies. Rather, we examine the process by which they were blamed, in discourse located in newspaper coverage of the events.

Jensen's argument about modernity can be applied to our study. It is possible that though media criticism is easier to articulate as a cause for these tragic events, perhaps truer culprits are modern issues and circumstances. Among these are an emphasis on commercial interests (e.g., ratings for Jenny Jones, money for the photos of Princess Diana, sales or ratings for the movies, music and video games mentioned in coverage of the Columbine shootings) or the alienation and disconnection experienced by many in contemporary life (e.g., the ostracism of the Columbine perpetrators, the claims of humiliation for the Jenny Jones assailant, the identification and adoration of Princess Diana).

Jensen presents the key media criticism arguments advanced by Macdonald (1962), that media and mass culture jeopardize the presence of high art; Boorstin (1972), that "pseudo events" created by the media and presented to audiences as fact obscure the truth; Ewen (1976), that consumer culture promotes an ideology of consumption that functions as an agent of social control; and Postman (1985), that television has led to the transformation of serious and important aspects of public affairs into entertainment, thereby robbing audiences 
of information they need to conduct themselves as citizens. Jensen identifies a common element in these criticisms: each suggests media change us, as audience members, by offering something more appealing or easier to make sense of compared to those things that would be better for us. Implicit in this criticism are the beliefs that there is consensus regarding what is good for society and that ordinary citizens themselves can't be trusted to know what that may be.

However, in media criticism the blame is often not placed on the audience for choosing lazy or flashy options; instead blame is placed on the media for duping the audience into doing so by presenting no better options.

These notions about audience preference and this sense of protectionism are central to our study. The angles chosen, words uses, and sources employed in reporting about these events (as part of the social process of news gathering) may reveal a similar "elite" protectionism and unflattering belief about the nature of audience preferences and desires. The news coverage may imply that members of the news media know what's best in order to protect the masses and sustain social order. By assigning responsibility to popular media for these three tragedies, "serious" journalists can adopt a prescriptive stance toward improving social conditions by leading audiences away from the ostensibly harmful and salacious content in popular media to which they are presumably drawn.

Jensen discusses the moral element in the comparison of tabloid journalism with "serious" journalism, with the distinction drawn between the two indicating "a moral tension between self-indulgence and self-denial" (pg. 
131). The loyalty of tabloid journalists to audience interests and therefore profit making is contrasted in media criticism to the loyalty in "serious" journalists to "higher" processes of rationality and the virtues of high culture. The distinction is made more obvious in the aspect of media-influence discourse that refers to the "lowest common denominator" presumably appealed to by certain types of media content such as tabloid journalism or popular media. A particular view of humans as being ill equipped for reason and inevitably drawn to more "shallow symbolic forms" (pg. 163) underlies this commonly used phrase. This is central to our discussion of popular media implicated by "serious" media in that implicit in that criticism is a sense of shamefulness assigned to those who supposedly "pander" to "base" human instincts toward violence (Columbine, Jenny Jones), intrusiveness (Jenny Jones, Princess Diana), and sex (Jenny Jones). An essay by Pauly (1992) about media mogul Rupert Murdoch in Carey's Media Myths and Narratives also informs this discussion of "elite" and "non-elite" media. Murdoch was criticized for his use of "promotional journalism" and accused of devaluing journalistic ideals by not "honoring the stylistic conventions that journalists used to defend the social importance of their occupation" (p. 243). Pauly discusses the defensive strategy of distinguishing between information and entertainment to define "elite" and "non-elite" media. Yet, he argues that this is an artificial construction:

Because mass-circulation dailies comprise vast and varied symbolic materials, different groups can argue that the 'essential' part is the one that they most enjoy or that sustains their sense of identification. Thus the 
professional journalist emphasizes the investigative role of the newspaper out of proportion to the actual number of stories undertaken (p. 254). In other words, the investigative, purely informational, "factual" content in a daily newspaper is a small portion of the whole, but is magnified in importance by those with a vested interest in arguing the difference between "serious" and tabloid journalism. This argument is at the center of our study which suggests in order to blame some aspects of media and popular culture, newspaper journalists must imply this content is fundamentally different (and comparatively "worse") than what they transmit to audiences.

The alleged dichotomy between "what audience members want" and "what audience members need" is also raised in Eason's (1992) essay in Carey's Media, Myths, and Narratives, in which Eason discusses the controversy surrounding the fabricated elements in Janet Cooke's award-winning news story, "Jimmy's World." Eason argues that journalism has experienced an evolution away from the reportorial function of transmitting facts and more toward the creation of "reality" with the words and elements of a story chosen by journalists. We argue similarly that the journalists in the coverage we reviewed in stories about these three high-profile tragedies create a reality in which popular media and popular-culture products bear responsibility for the tragedies. Although the journalists whose stories we review presumably did not fabricate any information they conveyed, they did choose to highlight certain "facts" that appear to have made their stories more marketable to a large 
audience while downplaying other "facts" that may have been deemed of less interest to readers.

\section{Factors Affecting Media Coverage}

A somewhat different though complementary view of the phenomenon of popular-culture culpability is seen from the perspective of Shoemaker and Reese (1996). Their approach examines how media content is influenced by factors in the context in which it is created. Though one could view their theoretical perspective as examining media content as shaped by external social processes in a unidirectional (external forces lead to media content) manner, we argue that their theory can be expanded to examine the interrelated, multidirectional, dynamic relations between all elements - content, producers, public. In Mediating the Message, Shoemaker and Reese identify five major spheres of influence on media content, from the most microscopic to the most macroscopic. We use these labels to identify sources of influence on the producers of news content as well as on the content itself. Though the labels are presented individually, we argue for their overlapping, multidirectional relationship with content as journalists go about the social practice of determining how to cover "the news." We introduce the levels of influence here briefly and will then apply them to each of the three events examined in this monograph.

The most microscopic level of influence on media content is the individual level, that is, the influence exerted by the individual reporter or columnist, the copy editor, and the editor-each person who has a hand in creating the news 
content. This can include deciding what constitutes news, selecting the angle of the story, writing the story, and editing it. Some of the factors that influence content decisions at the individual level are personal feelings, tastes and preferences, values, opinions, and the professional backgrounds and training of those directly involved in content decisions.

The media routines level focuses on the routines, or standard procedures, for gathering and disseminating news. Among the influences found at this level are news values - those characteristics that make an event newsworthy, such as deviance from the norm, sensationalism, prominence, proximity, timeliness, conflict or controversy, human interest, and impact on audience members or society as a whole. Other media routines include objectivity, the five "Ws" (answering who, what, when, where, and why in every report), pack journalism, competition, reliance on other media for information or for whole stories, localism (getting the local angle on a story that takes place far away), simplicity (offering pat "answers" because complex situations are hard to explain and hard for readers to understand quickly), and over-reliance on a handful of sources.

The next level of influence, moving toward a more macroscopic perspective, is the organizational level. Analysis at the organizational level focuses on the impact of policies, managers, and owners of the organization in which the media content is produced. It is difficult to discuss influences at this level, as we don't know what went on in each newsroom during coverage of these three events. However, the opinions of upper management or concerns of those in the 
circulation or advertising-sales departments can influence coverage, as can organizational policies such as the degree of autonomy allowed to each reporter.

The extramedia level has to do with elements and factors outside of the media organizations themselves, such as news sources, advertisers, government, interest groups, and the audience. This level includes actual, direct influences as well as the influence that news media personnel's perceptions of what these entities might do or how they might feel that also shape content. While influence of advertisers might weigh against extensive blaming of popular culture in news coverage, for example, pressure from some interest groups and activists, as well as governmental concern, could weigh toward the pursuit of this angle. In terms of perceptions of audience preferences, some journalists may believe that audiences want to see and read about violence, sensationalism, scandal, and the lives of celebrities. This perception could have a profound impact because giving the audiences "what they want" will presumably sell newspapers and space to advertisers. Thus, angles that have popular appeal may be advanced while more esoteric or abstract angles, such as the notion that it's society in general that is responsible or that a complex nexus of forces are at fault, may take a back seat.

The notion of audience preference is also a cultural one. de Mooij (1998) argues the one such preference that is culturally bound is American's adherence to a cause-and-effect paradigm. She argues that it is a cultural norm in the U.S. to expect to have a logical explanation for any given event and that any event has concrete and measurable answers to the question of what caused it. Journalists, if 
following this cultural norm or if presuming audiences follow it, may provide a concrete explanation rather than leave the tragedies unexplained. Subscribing to this cause-and-effect paradigm can be viewed as an individual influence on the part of reporters and editors, an extramedia influence that takes the shape of conceptions about audience preferences, or an ideological influence that entails broad-based cultural and societal beliefs.

The ideological level includes the influences that broad systems of beliefs and values have on the news-gathering process. Among the factors at play here are notions of "elite" and "popular" media, representations that define "mainstream" and "deviant" content, and the concept of hegemony. The latter suggests that entities enjoying political and economic power in existing societal structure will act in the interest of thwarting social change in order to protect their dominant status. We predict that these three case studies will show the use of defensive strategies when other media are, indeed, blamed. Through the use of labels such as "tabloid," "paparazzi," and "trash TV" to draw theoretically distinct lines, journalists may construct readings of their own stories as the dominant discourse and those of "tabloid" media and "trash TV" as deviant (Bishop, 1999; Eichholz, 1998). A subtext exists in this type of criticism that suggests a need to save people from their own tastes in media and popular culture. This is similar to the points raised by Bird (1992) and Jensen (1990) above, and is the central theoretical element of the study at hand. 
de Mooij's (1998) suggestion that as part of American culture, we-as members of society - need someone or something to blame whenever there is a tragedy, also has implications for hegemony and social order. In order for members of society to feel secure about the world around them, there has to be a rational cause, with a clearly identifiable source of blame, for each event. Thus, it is much more satisfying to place blame on a specific, tangible target -in this case, the non-elite media - rather than advancing the more unsettling notion that something is amiss in society at large.

\section{Case I: Princess Diana}

The first case study involves the death of Princess Diana of Wales and the automobile accident that took her life and the lives of Dodi al Fayed and Henri Paul on August 31, 1997. The accident occurred shortly after midnight in Paris when the Mercedes Benz in which the princess and her friend were travelling crashed in a tunnel near the Seine River. Dodi al Fayed and Henri Paul, the driver, were found dead at the scene. The Princess died a few hours later of injuries she sustained in the crash.

The event was reported in newspapers around the world. The larger U.S. and U.K. newspapers gave extensive coverage to the event in the days following the crash. For example, on the first day of coverage The London Observer ran 28 articles, The New York Daily News ran 10 articles, and The Atlanta Journal and Constitution ran four articles. This case study is based on analysis of those articles and others that were published in English-language newspapers from the day of 
the crash, August 31, 1997, through the day of Diana's funeral, September 6, 1997, when the focus of coverage shifted from the accident to the funeral. The articles were retrieved from the General News archive of Lexis-Nexis Academic Universe. In all, 507 stories were reviewed for relevant content, and those with relevant content were studied more closely. Just the Facts

Often, the first news reports of a tragic and unexpected event will present only the basic facts of the story, answering the fundamental journalistic questions of who was involved, what happened, when it happened, and where it happened, without speculation as to the causes of the event. It usually takes another day or more for the "how" and "why" questions to be answered.

This was not the case in the early reporting on Princess Diana's death. Answers to the "how" and "why" questions were included in the initial reports of the event because tabloid-press photographers were said to have been chasing the princess's car at the time of the accident. Approximately eleven photographers, sources said, some on motorcycles and others in a car, set out after Diana and Dodi's Mercedes when it left the Ritz Hotel in Paris. The photographers were apparently trying to get pictures that would confirm rumors of a romance between Diana and Dodi.

Several sources in the earliest stories claimed that the photographers caused the accident. Among them were Paris police, unspecified police, French 
journalists (their sources unnamed), a photographer for a London paper, AgenceFrance Presse (the French news agency), and British reporters.

No eyewitnesses to the crash were quoted in the early coverage - in other words, no source knew for certain that the photographers had actually caused the accident (and some sources even claimed that the car had lost the photographers). In spite of this, the idea that the photographers caused the accident became a part of every story reporting the facts of the event.

The Boston Herald began an article by Joseph Mallia (Aug. 31, 1997) with "Princess Diana and her companion Dodi Fayed were killed in a high-speed car crash early today in a tunnel near the Seine River in Paris, as their Mercedes was being pursued by photographers."

The Hindu of India began a story (no byline, Aug. 31) with "Britain's Princess Diana and her millionaire companion, Dodi El-Fayed, were killed in a car crash early on Sunday while being chased by photographers on motorcycles in a road tunnel in the French capital Paris."

The third paragraph of an Associated Press story that ran in The Buffalo News on August 31 read "The crash happened shortly after midnight in a tunnel along the Seine River at the Pont de l'Alma bridge. It came as paparazzi-the commercial photographers who constantly tailed Diana - followed her car, police said."

Popular-Culture Culpability 
During the week after the fatal crash, when coverage of the event was at its most intense, nearly every article contained at least one source who blamed the producers of popular culture for Diana's death. Among these were family members and family representatives, dignitaries, ordinary citizens, and journalists themselves. Other sources who blamed "the paparazzi," "the press," "the media" or "the tabloids" (sometimes including tabloid-style television shows) were an Arizona talk-radio host and many of his callers, Britons living in the U.S. (usually interviewed in pubs), unnamed TV commentators, and David Perel, executive editor of the American tabloid The National Enquirer. Perel was quoted in several newspapers as saying that reckless action by the paparazzi probably caused the accident.

Some family members of the crash victims extended the blame to all photographers who pursue celebrities for photos to be printed in tabloid newspapers. Ellen Tumposky and Mike Claffey of The New York Daily News (Aug. 31) reported “The dead Egyptian playboy's father, Mohammed Al-Fayed, blamed the tragedy on the paparazzi, who were being held for questioning by Paris police. 'There is no doubt in Mr. Al-Fayed's mind that this tragedy would not have occurred but for the press photographers who have dogged and pursued Mr. Fayed and the princess for weeks,' a spokesman for the Egyptian billionaire said."

The Houston Chronicle (byline Houston Chronicle News Services, Aug. 31) reported “(Michael Gibbons), a spokesman for Buckingham Palace, noting that 
the incident occurred while the couple were being chased by photographers, said it was 'an accident waiting to happen.'... he repeated the palace's anger at the actions of photographers who pursue the royal family around the world."

Other family members blamed not only tabloid-press photographers but also the editors and publishers of gossipy tabloid publications. The London Observer (article by Roy Greenslade, Aug. 31) was one of the first to report a scathing statement from Diana's brother.

"This is not a time for recriminations," said Earl Spencer, "but I would say that I always believed the press would kill her in the end. But not even I could imagine that they would take such a direct hand in her death as seems to be the case. It would appear that every proprietor and editor of every publication that has paid for intrusive and exploitative photographs of her, encouraging greedy and ruthless individuals to risk everything in pursuit of Diana's image, have blood on their hands today."

None of the first-day stories reporting the reactions of world leaders and diplomats (such as President Clinton, the Singapore government, and the Pope) contained quotes that blamed popular culture. However, on the second day of coverage, several French government officials made statements blaming the paparazzi, as reported in The Hindu (by Vaiju Naravane, Sept.1).

The president of the French Parliament, the former prime minister, Mr. Laurent Fabius ... said that death precipitated by paparazzi proves that 
"photos, words and attitudes can also, in a certain sense, kill. These people must now face their responsibility."...The government's spokeswoman, Ms. Catherine Trautmann, who is also France's Culture Minister, was more vehement in her denunciation of the paparazzi. Princess Diana was the victim of the stubbornness of the press, she declared. "The singlemindedness of the press had increased dramatically these past weeks ... The circumstances of her death have thrown up questions about the functioning of this profession and above all of our society," Ms. Trautmann added.

Among the stories that reported the reactions of ordinary citizens, most contained at least one source who blamed either the paparazzi who pursued the Mercedes or the press in general. Most of these "average-citizen" sources did not distinguish between the popular press and the elite press or their producers, nor did the reporters attempt to make any distinction for the sources. The blame laid by these sources was among the most vitriolic. The New York Daily News (article by Barbara Ross, Aug. 31) reported:

Britons in New York mixed their grief at Princess Diana's death with criticism of the press for its relentless pursuit of her.... Beverly Dorking, 25, of Leeds in northern England, said, “...she's been dogged and hounded by the media. They've been in her face since she was 19, and now they've taken away the world's most popular woman." Nicola Shigley, 24, of northern England, predicted a backlash against the media. 
She accused the media of spending "the last 10 years trying to put the woman to an end."

The San Diego Union-Tribune (article by Lillian Salazar Leopold, Aug. 31) reported “'The press has a lot to answer for,' said Mary Simpson, also of Liverpool. 'They hounded her to death. Literally, now.'”

The Seattle Times (article by Chris Solomon, Aug. 31) reported “Mitch Lease, $23, \ldots$ reflected bitterly on the circumstances of her death, a chase by photographers. 'I think the media should have given her a break a long time ago, and now they've killed her.'"

The London Observer (article by Roy Greenslade, Aug. 31) reported “In one bitter outburst on BBC TV, a woman demanded that a reporter and his cameraman stop filming. 'You've done this to her,' she screamed. 'You're to blame. The media, the papers, all of you.'"

Some articles blamed popular culture by quoting other publications and thereby demonstrating what seemed to be a world-wide consensus as to who was to blame for the tragedy. A London Observer article (byline: "foreign staff," Aug. 31) read:

The French newspaper Liberation gave over its whole front page to a picture of (Diana) with the headline, "One photo too many."... Italy's La Stampa took up the same theme, stating tersely: "Dead for a photo".... Hong Kong newspapers agonised over their own home-grown paparazzi, with the Oriental Daily News recalling that a local pop singer, Leslie 
Cheung, had crashed his Porsche while being pursued by photographers. It branded paparazzi as "criminals of a thousand years." The Daily Star, a Bangladesh newspaper, said that "Western press and society will need to embark on a long search of their souls to come to terms with the sense of guilt Diana's death must generate."

Alongside the just-the-facts stories and reaction stories were articles focused primarily on the causes of the accident. Many of these stories found some aspect of popular culture (either the photographers who chased Diana's car that night, tabloid-press photographers in general, tabloid newspapers, the editors and publishers of tabloid newspapers, or any member of the press who had purchased paparazzi photos) to be at fault. The tone of these articles was often angry and disgusted.

Earl Spencer's statement was used in several of these stories as a starting point for further discussion of the role of the paparazzi in Diana's death. Dave Walker, writing for The Arizona Republic (Sept. 1), began such a story by asking "Do the media have blood on their hands for the death of Princess Diana? That's what her brother, Earl Spencer, suggested in the aftermath of the car wreck..."

Walker went on to cite several sources who agreed with Spencer, including Dodi's father, Mohamed al Fayed, unnamed network television commentators, and Phoenix-area talk-radio host Charles Goyette, whom Walker quoted: "'The media are clearly to blame,' said Goyette, summing up the 
majority opinion among his callers. 'The consumers of this trash don't have the culpability, the media do.'"

An article in The Glasgow Herald (by Catherine Macleod, Sept. 1) quoted a source who followed Spencer's lead and blamed all the producers of tabloid newspapers: “ ...the Prince of Wales's biographer Jonathan Dimbleby said: 'It isn't only the reporters and photographers, it's those who hired them.' He added: 'It's the editors and proprietors who too often offer glossy excuses about the public interest who need now to examine their consciences."'

Some of the stories that discussed causes were actually editorials expressing the views of the writer or writers. For example, The London Observer (no byline, Aug. 31) expressed the following opinion: "Anyone in the British Press who has bought and used the pictures snatched by paparazzi on so many previous utterly private occasions helped ensure that the ravening pack would be on the trail on Saturday night."

Some of these articles were written in a narrative style, retelling the facts of the story dramatically while characterizing the photographers as degenerates. For example, Michael Daly of The New York Daily News (Aug. 31) wrote:

No matter how fast her car sped through the Paris night, the paparazzi on the motorbikes were sure to stay right behind her, for she was with the man said to be her lover.... (T)he following Sunday, she was swarmed by those only interested in violating her private life... They were still after the couple when she arrived in France. The hounds kept baying, right up 
to early this morning, when motorcycles sped after Diana's car along the Seine. Her pursuers were right out of the 1961 movie "La Dolce Vita," in which a photographer named Paparazzo chases his prey on a motorscooter.... (T)hey chased the biggest score ever right to her death. The frenzy that began with "The Kiss" ended in two children being left without their mother.

Similarly, Luke Harding, Owen Bowcott, John Hooper, Paul Webster, Alex Bellos, Stephen Bates, and Chris Mihill of The London Observer (Aug. 31) wrote: Even before Princess Diana and Dodi Fayed had strolled through the baroque central corridor of the Ritz Hotel in Paris...the paparazzi were lurking in wait... (Diana and Dodi's) presence was common knowledge among the small, ruthless, multilingual band of photographers who pursue her, very lucratively, for a living.... Around 7 p.m. on Saturday Diana left the Ritz in a chauffeur-driven car to do some shopping in the Champs Elysee. The press pack were, reportedly, in close pursuit.... Quite a few stories blamed "the press" in general or "the media" in general, not distinguishing the mainstream press from the tabloid press. Among these were stories reporting that Diana herself had condemned the practices of the British press in an interview published in a French newspaper the week before the accident. J. Frank Lynch of The Atlanta Journal and Constitution (Aug. 31) reported “In Great Britain, 'the press is ferocious,' Diana said in the article in the 
French daily Le Monde. 'It forgives nothing and is only hunting down mistakes. Each act is twisted; each gesture is criticized.'"

Sharing the Blame

A number of stories about the causes of Diana's death divided the blame among several culprits. One of these culprits was Henri Paul, the driver of the Mercedes. On the first day of coverage, many articles noted that Paul had been driving at a speed well above the limit and that he lost control of the car, thus implying that the accident was at least partly his fault. When the news of Paul's very high blood-alcohol level (which was more than three times the French legal limit) was released on day two, he became the target of finger-pointing in many more articles. However, none of the stories that blamed Paul let the producers of popular culture off the hook completely. An editorial in The Arizona Republic (no byline, Sept. 3) argued:

The swift and reckless rush to judgment, the desire to fix certain blame for the death of Diana, is also destructive and promises to leave victims. Misplaced blame might mask sorrow's pain, but it does not heal.

Diana Spencer, queen of celebrity, died from the impaired judgment of millions. We'll name a few. The paparazzi, a subset of photojournalists identified first and perhaps forever as the villains who ended the strange, fairy-tale existence of a lovely young woman, continue to receive disproportionate blame. Seven photographers face some type of charges related to the fatal crash.... So what of the judgment of those 
editors and publishers who buy sleaze and resell it under some loose definition of news? Impaired? Morally warped? Yes. ... And, so what of the judgment of millions of readers who purchase the product now blamed for the death of a princess? Impaired? Warped? Yes. ... However, in this tragedy, the person whose impaired judgment seems most responsible for the death of Princess Diana, is the man behind the wheel of the car carrying her and her boyfriend....

One of the few articles to seriously consider the culpability of Henri Paul was published by The Boston Globe (Sept. 1). (This story also contained several sources who blamed the paparazzi at the scene and the press in general.) Author Peter S. Canellos wrote:

Ralph Whitehead, a journalism professor at the University of Massachusetts, said all the hand-wringing over the misdeeds of media is “a momentary hysteria."

Unless proof emerges that paparazzi on motorcycles actually interfered with the progress of Diana's car, responsibility for the accident should rest with the driver, he said.

The Mercedes limousine was traveling faster than 60 miles per hour-perhaps much faster-in a tunnel where the speed limit is 30 , police said. The princess and her companion, Dodi Fayed, did not appear to be wearing seatbelts. 
"What would Diana and the rest of the people in the car have lost if they'd been overtaken by photographers?" Whitehead said. "If you're a celebrity, you have a right to regard the paparazzi as a pain in the neck. But it's not the right response to put your life in jeopardy by speeding away."

For a few days, there was a bit of a tug of war between those sources representing the photographers (primarily their lawyers) and those representing the driver (the Fayed family and Paul's co-workers). Some of the stories printed on days two through seven offered opinions as to which party deserved more blame, while others blamed Western society as a whole for its fascination with celebrities. In an article called “Time Has Come to Point Finger in Right Direction," Steve Wilson of The Arizona Republic (Sept. 3) wrote "I would like to interrupt all the finger-pointing in Princess Diana's death - do the paparazzi or the drunken driver deserve the most blame? - for this important message: It's the culture, stupid. Or more precisely, it's the stupid, celebrity-obsessed culture." Mickey H. Osterreicher of The Buffalo News (Sept. 4) wrote:

As a photojournalist, I am ashamed and embarrassed by the accusations that "paparazzi," photographically pursuing the princess, were the cause of the accident. Given that factor, along with alcohol and excessive speed, the comparative negligence in this case would appear to be endless. In a larger sense, we are all somewhat responsible. This tragedy sadly illustrates the life and times in which we live. 


\section{$\underline{\text { Popular-Culture Exoneration }}$}

In the other cases we examined, some journalists and sources came to the defense of the popular-culture products that were widely blamed for the tragedies. In the case of Diana's death, the paparazzi, the tabloids and their producers were never fully exonerated. However, quite a few stories published in the days following the crash placed primary responsibility on the readers of tabloid newspapers - for encouraging the practices of the paparazzi.

An editorial in The Atlanta Journal and Constitution (Sept. 1) blamed the consumers of popular culture: "Princess Diana, perhaps the most recognizable woman in the world, was so beautiful and compassionate that people everywhere fell in love with her. And then they loved her to death. The insatiable demand for gossip and pictures involving Diana set the stage for her tragic end." The editorial went on to blame the tabloid audience more explicitly: "The way to stop the stalking is to quit buying the trashy publications that pay for paparazzi pictures. This week, many of Diana's loyal fans will be weeping for their tragic heroine, but if they had not purchased the papers that exploited her in the first place, she might not be dead."

Others concurred. The Arizona Republic's Dave Walker (Sept. 1) wrote "Some observers blame tabloid readers for creating the high-dollar market that would send photographers on a high-speed chase through Paris." Walker cited “Mary-Lou Galician, an associate professor at the Walter Cronkite School of Journalism and Telecommunications at Arizona State University" as saying "that 
paparazzi command huge fees for celebrity photos because there's a market demanding them. 'The mathematics suggest that millions of people want these things,' she said. 'The public has to assume ultimate responsibility and not blame the messengers.'"

Interestingly, several other factors could have served to exonerate the photographers and tabloids, at least partially, but these factors were largely ignored by the writers who sought to answer the "why" question. Among these factors are the fifteen minutes it took for an ambulance to reach the Mercedes, where Diana was rapidly losing blood; the fact that neither Diana nor Dodi was wearing a seat belt; the claim made by a few sources that the Mercedes had escaped the photographers before the crash; and, finally, the fact that no one really knew if the photographers actually caused the accident. Instead of emphasizing or even just exploring these factors, the newspapers chose to focus most of their coverage (and most of the blame) on the paparazzi, the tabloids, their editors and publishers, and the readers of these popular publications.

\section{Connections with Theory}

Many of the theoretical arguments made by Pauly (1992), Eason (1992), and Bird (1992) were apparent in this case study of press coverage of Princess Diana's death. The fact that the photographers who were following Diana were employed at tabloid newspapers invited the discourse of "serious" versus "tabloid" journalism seen throughout the coverage. The tone of condemnation and blame in coverage of Diana's death was directed squarely at the tabloids 
rather than at press coverage in general, just as in the pointed criticism of fabricated news stories (Eason, 1992) and the reproach of the practices of Rupert Murdoch (Pauly, 1992). As Bird (1992) found in her analysis of tabloid newspapers in general, the tabloid photographers, in this particular situation (as well as editors, reporters, and owners) were implicated for their "base" profitseeking and sensationalism which was implicitly contrasted with the elevating public service function of the "elite" press.

The theoretical contributions of Jensen (1990) also apply. In fact, the Princess Diana coverage stands out because the audience was also drawn into the blame for its apparent attraction to sensationalism and intrusive fascination with the private lives of famous people. This element of the coverage reveals a view of the general public as drawn to "what is bad for them" that Jensen discusses as an underlying element in major strains of media criticism. By implicitly making a distinction between the "popular" and "elite" news media, the newspapers we reviewed were able to deflect criticism from themselves and take an allegedly prosocial stance as watchdogs standing guard against the practices and content of other media institutions, thereby protecting the public.

Finally, we may also examine the press coverage of Diana's death via the levels of influences of news media content as advanced by Shoemaker and Reese (1996). At the individual level, for instance, reporters may have empathized with Diana's plight of being followed and photographed all the time and thus been more inclined to blame the accident on those who hounded her. Individual 
reporters (and their higher ups) may also have been motivated to try to make sense of and elevate the status of the death of Diana because her life was so extraordinary. In other words, death caused by a car crash-even one in which the driver was under the influence of alcohol-seems too mundane for a Princess and a woman of such stature. Thus, the pursuit of that car by paparazzi adds a glamorously tragic element befitting a Princess as well as a moralistic element that may help channel the widespread anger and sadness caused by her death. This is exacerbated by the immediate removal of Henri Paul from ongoing blame due to his own demise. The tabloids provide an enduring, monolithic institution to blame rather than one unknown and unknowable individual. Finally, the professional background of newspaper journalists might have made them prone to view the paparazzi as reckless or unruly because freelance photographers are not required to have journalism training or to adhere to a professional code of ethics, whereas most newspaper journalists are.

Media routines were also apparent in the coverage. The selection of sources certainly shaped the stories that were written. Many newspapers reported either the prepared statements of the victims' family members or the comments of celebrities, all of which sharply criticized the paparazzi. Localism produced some of the most vehement sources. The Britons interviewed in American pubs were quick to blame not only the photographers who chased Diana's car but all tabloid media. This would also serve to separate the "elite" news media from the presumed culprits (though, in the case of Diana's death, a 
few writers did admit to guilt on the part of the "elite" media, especially after the wall-to-wall coverage of Diana's death in the "elite" media).

Extramedia influences on coverage were also apparent. Some sources called for government intervention in the practices of tabloid photographers after Diana's death. Notions of audience preference may well have facilitated the pursuit of the paparazzi angle through the view that many readers of the "elite" press would welcome the criticism of the tabloids and find this element of the event emotionally charged and fascinating.

Influences presumably occurred at the ideological level as well. The potential dissonance involved in newspapers reprimanding other types of print media was alleviated by the strategy of distinguishing between "them" and "us." This is apparent in the many markers labeling tabloids as a separate entity in "elite" press coverage. We can also see evidence of the cultural belief in the cause-and-effect paradigm (de Mooij, 1998) in press coverage that is, in fact, magnified here due to the fact that Diana was the subject of admiration and adulation in many parts of the world. Her revered status may well have heightened the typical North American tendency to try to find a cause for every event, a solution for every "problem." The criticism of the paparazzi, as well as the alcohol level of the driver, surfaced as an attempt to explain what was essentially a senseless death and thereby diminish readers' fears, discomfort, and, in some cases, grief. Finally, ideological beliefs about the nature of the masses were also apparent in the Diana case, as some newspapers placed part of 
the blame squarely at the feet of the public, whose taste for sensationalism, the papers claimed, is merely answered by tabloid publications.

\section{Case II: The "Jenny Jones" Murder}

In 1995, television talk-show host Jenny Jones arranged for Jonathan Schmitz, 34, to appear on her show as a part of her signature "secret admirer" segment. Schmitz was told in front of a national audience that his secret admirer was Scott Amedure, 32, a gay friend. Three days after the show was taped, Schmitz shot Amedure to death. News coverage of the event quickly focused on the way Schmitz was brought in front of a national audience and "humiliated" as the subject of a gay fantasy. Subsequent news coverage was dominated by fingerpointing - who should be blamed for the death of a talk-show guest? Schmitz was convicted of murder in November 1996, and in May 1999, the Amedure family won $\$ 25$ million in a negligence suit brought against the "Jenny Jones Show" and Warner Brothers, Jones' employer.

Over the last five years in which the story has been reported, the object of blame has fluctuated. News stories about the Jenny Jones talk-show murder centered around four points in time: the initial shooting, a rash of follow-up stories blaming "trash TV" for the murder, Schmitz's first trial, and Schmitz's second trial. The analysis below reflects quotes taken from newspapers across the country from the day after the murder through August 1999 when Jonathan Schmitz was convicted for a second time in the shooting death of Amedure. Articles were retrieved using the news category in ProQuest. In all, 326 articles 
with relevant content were reviewed. This case study attempts to illustrate how the print news media covered the Jenny Jones case, with an emphasis on analyzing the sources of blame.

Just the Facts

News stories on the first day after Scott Amedure's death reported the event as just another murder. Furthermore, news stories published that day implicated Jonathan Schmitz alone for Amedure's murder. While the first-day stories mentioned the "Jenny Jones Show" because both men were guests on the show, neither the show nor its producers was directly implicated for the murder until a few days later. Shauna Snow, writing for The Los Angeles Times, dealt with the facts alone in her story on March 10, 1995.

A gay man who took his penchant for talk shows to heart and appeared on the "Jenny Jones Show" to reveal his secret crush on a heterosexual man has been shot dead, and police said the object of his affection admitted the killing.

All other stories examined that were published on the first day after the event contained a similar, just the facts approach.

\section{Popular-Culture Culpability}

After initial news accounts reported who, what, where, when, and how, analysis and interpretation began to appear in stories about the murder. The "Jenny Jones Show" and the show's producers came under fire the day Jonathan Schmitz was arraigned on first-degree murder charges. In a Washington Post 
article (no byline) on the second day after the murder, March 11, 1995, the finger pointing at the "Jenny Jones Show" began.

Producers of the "Jenny Jones Show" have come under attack by Michigan prosecutors who allege the nationally syndicated talk show is partly responsible for the murder this week of a guest who professed to have a crush on another man.... Oakland County Prosecutor Richard Thompson said the talk show's "ambush" tactics - in which guests learn of shocking personal details on camera - may be partly to blame for the death.

A Tacoma News article published March 11, 1995, was one of many newspapers to describe the segment as "ambush television."

Call it ambush television. It's the latest weapon in daytime talk-show wars, and now it's had deadly consequences. The formula is simple: Bring guests on the air, set off conflict and embarrass them before a national TV audience. Maybe even embarrass them to death...

The "Jenny Jones Show"' brought on John Schmitz, a 24-year-old man from Orion Township, Mich., and told him that a 32-year-old acquaintance, Scott Amedure, was his secret admirer. Today, Amedure is dead and Schmitz has been charged with murder. The "Jenny Jones Show" was further implicated for Amedure's death later in that first week of news coverage after Prosecutor Thompson alleged the talk show was not only partially responsible for the murder of Amedure but also for 
the "poisoning of society." An article in The Detroit News quoted Thompson as saying Schmitz was "ambushed on national TV, the suggestion being that all Schmitz did was ambush back" at Amedure.

While the other two cases studied here were front-page stories from day one, the "Jenny Jones" talk-show murder only began to make the front page after the talk show's culpability became a part of the story. Most stories, such as this story from The State Journal Register published on day two, contained harsh criticism directed toward the show and its producers and cited ratings as the rationale behind the segment.

A talk show focusing on "Secret Admirers" led to the killing of one guest, allegedly by another. Is 'The "Jenny Jones Show"' to blame? And was this a tragedy just waiting to happen? Yes to both questions, according to talk-show critics, who argue that anything goes to boost ratings.

As the story became more prominent, analysis of the event became the "new" news. The event was frequently the subject of newspaper editorials and columns, and these columns went beyond implicating the show and its producers for Amedure's murder - the authors accused the talk show of "trashing society." By the time this Phoenix Gazette story ran on March 14, many of the "elite" newspapers had spent the previous three days analyzing the culpability of the talk show and its producers.

"Our concern now is for the family and friends of the deceased and (for) maintaining the sanctity of the police investigation and the case," Jim 
Paratore, president of Telepictures Productions, which produces the "Jenny Jones Show," said.

His concern comes a couple of shotgun blasts too late. And his rejection of blame is cynical and without merit. Do Jones or the show's producers ever investigate the temperaments or personality traits of those they seek to embarrass? Did they know anything about Schmitz, or about submerged feelings he may have about homosexuality?

Obviously not. Nor did they care. Someone else pulled the trigger, but they were the ones who blindly spun the chamber. For that reason, they are all accessories. Howard Rosenberg of The Los Angeles Times on March 17, 1995, blamed the daytime talk shows for what he called... ...rampant misbehavior on the part of daytime television talk shows that play loosely with the lives of some of their guests by seeking to embarrass them with the cameras rolling.... Schmitz is surely a man driven by inner demons that "Jenny Jones" didn't know or care about when its staff plotted this high-risk farce, which, in the case of these two men, was based on the premise that a homosexual coming on to someone who is apparently straight equals titillation.

Elsewhere in the column, Rosenberg blamed the "Jenny Jones Show" for driving a mentally unstable Schmitz over the edge in the cause of ratings. "If Schmitz is guilty, he's the one who pulled the trigger. But if so, it was 'Jenny 
Jones' along with the laws allowing him to purchase a shotgun with apparent ease that provided the trigger."

It was at about this point (one week after the murder) that the theories of "who is at fault" seemed to coalesce among the different sources. Schmitz's attorney wholeheartedly defended his client's actions, suggesting the talk show "goaded a lunatic" to take desperate action. Many of the news stories published at the same time took a similar tone. It was in these articles, published from two days to two weeks after the murder, that the popular-culture culpability angle became so evident. Newspaper headlines alone clearly directed responsibility to the talk show.

"Critics Link Slaying to Contentious Talk Shows" (News Tribune, March 11, 1995)

"Ambush-Style Talk Shows Are Playing with Fire" (Detroit News, March 11, 1995)

"Critics Say Talk Show Partly to Blame in Talk-Show Slaying" (Sun-Sentinel, March 11, 1995)

“TV's Gutter Talk-Sleaze Talks a Terrible Price" (New York Newsday, March 13, 1995)

Nationally known newspapers such as The Detroit News, The Washington Post, The L.A. Times and The Chicago Tribune covered the murder and arraignment from a seemingly objective standpoint; however, the sources used in each of the stories-Schmitz's attorney and Schmitz's family members--represented only one side. The tone in the newspaper stories wasn't overtly critical, but the inclusion of some points of view and not others suggested the "elite" media were 
condemning the actions of the daytime talk shows. Not surprisingly, the Detroit newspapers dedicated a great deal of space to the story, and Ron French of The Detroit News wrote several articles and columns dealing with the issue of culpability (Dec. 11, 1995).

His (Jonathan Schmitz's) parents can't understand how a son who cried when he ran over a toad with the lawn mower could shoot a man. "It's darker on this side of the gun," Allyn Schmitz said. "This terror we had lived with came in a worse form. He didn't kill himself, but he killed himself in another way. His life is taken away by prison and by Jenny Jones."

Neal Gabler of The Houston Chronicle also faulted the show for putting the gun in Schmitz's hand.

How the producers of the "Jenny Jones Show" must have grieved. During a segment entitled "Secret Admirers," they had surprised a male guest expecting to meet a female admirer by springing a male acquaintance instead...Naturally, the producers made professions of regret, but one suspects what they really regretted was the killer's indecency of not having pulled out his rifle and committed the crime before their cameras. Now, there would have been a ratings coup.

The "Jenny Jones" talk-show murder all but disappeared from newspaper headlines within the first month after the murder. However, as the case moved closer to the trial stage, news stories blaming products of popular culture started 
to reappear. It was at this time in late 1995 when many politicians jumped on the bandwagon of condemning the daytime talk show for broadcasting "daytime TV smut." It was also during this time that parents and politicians alike decided daytime television needed regulation. Harry Levins' story in The St. Louis Post Dispatch, Oct. 28, 1995, reported on a "band of influential Washingtonians" who led a campaign of taking the talk show to task, calling it "a matter of citizenship." The main critic of the daytime talk shows was former Education Secretary William Bennett, quoted in The Detroit News.

"There was a time," Bennett said Thursday, "when personal failure or marital failure, subliminal desire, and perverse tastes were accompanied by a sense of guilt or embarrassment. Today, these are a ticket to appear on the Sally Jesse Raphael show to be broadcast for children to watch," Bennett said. "This cultural rot is polluting America."

Many news organizations relied regularly on sources such as Prosecutors Thompson or Burdick or politicians such as Bennett, Joseph Lieberman or Sam Nunn, who were very outspoken about the liability of the talk show. Thompson readily blamed the "Jenny Jones Show," Jenny Jones herself, and the talk show's producers for the murder. Friends and family members of Amedure rarely appeared as sources in news stories. Yet family members and friends of Schmitz were frequently quoted, as were psychologists and analysts hired by the defense team. Furthermore, newspapers used Thompson and Burdick as sources more 
than anyone else. Therefore, the most critical voices were the ones most frequently cited.

In addition to presenting one-sided stories, news organizations pandered to the audiences of the popular-culture products they were criticizing by giving the story so much news coverage. Joanne Jacobs of The Tulsa World, Nov. 14, 1995, reported on what it was she thought the public wanted.

It's estimated that a million teen-agers and 650,000 pre-teens turn on daytime sleaze, and absorb its perverted values.... Trash-talk hosts claim their shows serve as morality plays, with the studio audience cast as judges. This lets viewers revel in the lurid confessions and confrontations. Then they get to condemn it. Small-town morality lives, only with hotter gossip and a better choice of sins.

\section{Exonerating Popular Culture/Sharing the Blame}

As the implication of a popular-culture product in the murder case became old news, new theories of blame started to circulate. During this time, a few weeks after the murder, two key suspects shared the blame for Amedure's murder with the "Jenny Jones Show" - Jonathan Schmitz himself and what was called the "homosexual panic defense." Paul E. Gainor, reporting for The Detroit News, March 26, 1995, was one of many who explored this theory.

Richard S. Sinacola, a Royal Oak therapist for 12 years...says the case of Scott Amedure and John Schmitz...may have involved homosexual panic as a trigger point.... Sinacola theorizes that Schmitz "couldn't handle the 
fact that it involved homosexuality." For him, it touched on some deepseated homophobia.... What he was killing was not so much the victim, but his own sense of homosexuality in the victim.

The "homosexual panic defense" theory quickly took center stage in news articles after stories about Jenny Jones' irresponsible behavior began to subside. The homosexual panic defense made headlines a few weeks after the murder and reappeared as a secondary object of blame when the media began covering Schmitz's first trial. From The Seattle Times, reporter not listed, on October 6, 1996:

Focusing on the "Jenny Jones Show" shifts blame away from the defendant to homophobia... Society's problem is not that these TV shows are on. Society's problem is that we've created a world where a guy feels he can go out and kill a guy because he is gay. As the "hate, not humiliation" theory became the new focus of news stories, a small contingent began to blame Schmitz again for the murder. Robert Strauss of The Los Angeles Times said that Schmitz would have to be pretty gullible to have no idea what he was in for on the "Jenny Jones Show." Strauss argued that even if the show's producers encouraged Amedure to be flamboyant toward Schmitz, Schmitz still purchased the gun, sought out Amedure, and killed him.

\section{Unique Elements}


While Scott Amedure's death is undoubtedly a tragedy, his death did not reach the magnitude, in terms of press coverage or public outrage, of the Columbine High School shootings or Princess Diana's death. The "Jenny Jones" talk-show case also differed from the other two cases in that it involved two trials and a negligence suit brought against the show. In the late fall of 1995, hearings on the "Jenny Jones" murder case began, and throughout late 1995 and 1996, the "Jenny Jones" talk-show murder began making news again. While more than six months had passed between the murder and the first round of hearings, Jenny Jones, the show, and its producers still remained the objects of blame for Amedure's murder. As the trial neared, Schmitz's new defense attorney again tried to focus on the talk show's tactics. While on the stand, Jenny Jones maintained that Schmitz knew his secret admirer could be a man or a woman.

Ron French, for The Detroit News on February 21, 1996, wrote several stories about the trial stages of the case.

... defense attorney James Burdick will try to deflect responsibility for the slaying from his client to the "Jenny Jones Show" and its ambush interview tactics. Schmitz claims he was misled by producers who persuaded him to fly to Chicago to appear on a show about secret admirers.

On November 12, 1996, Jonathan Schmitz was convicted of second-degree murder, yet jurors for the trial said the show deserved at least some of the blame. 
Ron French of The Detroit News, November 13, 1996, covered the case's outcome from the jury's point of view.

"We saw the show as a catalyst for this," said juror Joyce O'Brien. "They destroyed one person's life and his family, and another young man is dead and his family ruined. It is a terrible injustice all because of the show."

As the trial came to a close, reporters from the "elite" media again began bashing the "Jenny Jones Show," the show's producers, and daytime TV for the "corruption of society."(The Boston Globe, AP story, Dec. 8, 1995). An Associated Press story, written by Frazier Moore, discussed the details of the verdict in a November 29, 1996 column.

Obviously Jonathan Schmitz wasn't prepared for what he got by Jones or any of the Jenny Jones staff. Quite the opposite. Evidence indicates that for the sake of lively talk TV, Schmitz was set up to believe he would be meeting the girl of his dreams.

Instead, he met Jenny Jones.

After the much-publicized trial and verdict, the two years following the trial, 1997 and 1998, were fairly quiet. News of the murder and trial popped up sporadically and mostly in the form of editorials. Schmitz was convicted in 1996, but in 1998, his conviction was overturned on a technicality in an appeals court. In May of 1999, a jury awarded the Amedure family $\$ 25$ million in a negligence 
suit against the "Jenny Jones Show." From a Los Angeles Times story (byline merely indicating it was from wire reports) on May 15, 1999:

A jury finds the "Jenny Jones Show" liable for the 1995 shooting death of Scott Amedure, a gay man who admitted during a never-aired show that he had a crush on Jonathan Schmitz. The jury awarded \$25 million in damages to Amedure's family, saying the show tricked Schmitz and humiliated him into committing the murder.

In September 1999, Jonathan Schmitz was convicted for the second time in the death of Scott Amedure. Circuit Judge Wendy Potts handed Schmitz a 25 to 50-year sentence - the same sentence he received in his first trial.

The \$25 million civil-suit award for the Amedure family represents a new trend in state and federal courts holding entertainment media liable for a tragedy. Culpability in the "Jenny Jones" talk-show murder case was easier to prove than the culpability of the violent video games, music, and films linked to the Columbine High School shooting and of the paparazzi linked to the death of Princess Diana. The title of the segment, "Secret Admirers," the "ambush-style" tactics, and the notion that a talk-show guest was allegedly "goaded" to act flamboyantly have all been cited as evidence that the show and its producers incited the murder.

\section{Context of Popular Culture Blame}

At the same time the entertainment industry was being held accountable for Scott Amedure's death, news of other tragedies, including the Columbine 
High School shootings, hit the airwaves, and some producers of popular culture were again the target of blame. From the time of the murder to the time of Jonathan Schmitz's first trial, the "Jenny Jones Show," the producers of the show, daytime talk shows in general, homophobia, and Schmitz had all been blamed for the death of Amedure. The news stories acknowledged Schmitz was responsible for pulling the trigger; however, many reporters seemed intent on finding an additional source of blame. Through the selection of sources used in news stories to the focus of the news stories themselves, the "elite" media seemed to assign blame to the "less-than-legitimate" talk shows. Within a month after the murder, many of the "elite" media jumped on the bandwagon of accusing the popular media of polluting America. From The Washington Post, on October 31, 1995:

Still, there's no question many talk shows exploit and often humiliate people for entertainment-especially the ambush-style programs like the infamous Jenny Jones episode that was accused of sparking a murder. Some of the news stories even tried to draw distinctions between audiences of the "trashy" daytime talk shows and the audiences for other newsoriented programs. Sharon Waxman of The Washington Post described viewers of the daytime talk shows as "gullible...often unemployed...leeches" who had nothing better to do than to live vicariously through the lives of other "trailer park trash." 
This cycle of blame became all the more evident as Jonathan Schmitz headed into his first trial and then his second trial. "Elite" newspapers such as The Washington Post, The L.A. Times, The Dallas Morning News, The Detroit News, and The Chicago Tribune tried to draw a clear distinction between themselves and the popular media. Furthermore, these news outlets criticized the talk shows for uncovering secrets, exposing wrongdoings, and "harping on the perversion in society." Yet many of these publications were doing the same thing by giving the story so much coverage. The difference is that the talk shows were reaching one audience, and the "elite" media used the same "trash" to reach another audience.

During the four-and-a-half-year-long evolution of the story, several theories of blame circulated. While the blame was shared, the daytime talk shows took the biggest hit for causing the problem, "cultural pollution." Jonathan Schmitz's lawyer, James Burdick, said when Jenny Jones asked her television audience, "Is your life better than television?," culpability rested in her hands and in the hands of the show's producers. Burdick's contention is that in Jones' quest to focus on the drama of interpersonal conflict in a public forum, she theoretically put the gun in Schmitz's hands.

Connections with Theory

Pauly's (1992) discussion of the "elite" media's criticism of Rupert Murdoch parallels the "elite" media's criticism of the talk shows in the "Jenny Jones" case. Rupert Murdoch was accused by many in the "elite" press of devaluing journalistic ideals, and in a similar sense, journalists covering the 
"Jenny Jones" case accused the talk shows of not maintaining a high standard of practice. This can be seen quite clearly as many newspaper reporters covering the story tried to distinguish themselves as "serious" journalists.

Media mogul Rupert Murdoch was criticized for his style of promotional journalism (Pauly, 1992), and the news organizations covering the "Jenny Jones" story capitalized on the promotional qualities of the pop-culture products they were criticizing by giving the story so much news coverage. The news media would have a difficult time rationalizing the prominent play the story received, especially the length of time the story was in the news, because over the course of time, new details were not uncovered. More simply, the story was essentially old news with a high level of sensationalism and a presumed high level of public interest. It seems fairly clear that as news editors made decisions regarding the newsworthiness of the story, promotional journalism was a driving factor in continued coverage.

The examples from the "Jenny Jones" case parallel Bird's (1992) discussion of the way "serious" journalists speak out about "low taste." The "elite" journalists made overt references to the media producers they felt were responsible for Amedure's death. Adjectives such as "trashy" and "tabloid" clearly placed the talk shows in a very different category from the "elite" journalists; thus, by distinguishing the talk shows as a media product very different from what the journalists were producing, the journalists were able to keep the blame away from themselves. The "elite" media's classification of the 
talk shows as "smut" entertainment is what Jensen (1990) would classify as an assumption of the masses as the "lowest common denominator." As the "elite" newspapers critiqued their popular media counterparts by using words such as "trash," "smut," or "tabloid," they elevated their own status by drawing a clear distinction between themselves and those ostensibly not like them.

One application of Jensen's (1990) theoretical framework to this study is an understanding of how the popular media were blamed for each of the tragedies. In the "Jenny Jones" case, the "elite" journalists accused the talk shows of pandering to the "sick" predilections of viewers, in a sense, doing anything for ratings. The talk shows were blamed for giving audiences what they wanted rather than news and information they needed. In many news stories, the "elite" journalists explicitly condemned the talk shows, the talk show producers, the talk show guests and the talk show viewers of lowering the cultural standard of art in America. This analysis can also be tied to McDonald's (1984) discussion of journalists speaking out against "low taste." In the "Jenny Jones" case, some newspaper quotes actually addressed this issue explicitly, arguing that part of the blame lies squarely at the feet of the public whose taste for sensationalism is merely answered by television talk shows.

Shoemaker and Reese's (1996) discussion of the five levels of influence on media content is central to explaining much of the coverage of the "Jenny Jones" case. At the individual level, reporters and columnists frequently took the show to task in the form of editorials, thereby providing an outlet for their own 
unfavorable views of the show and others like it. The newspaper journalists covering the "Jenny Jones" case often seemed to have taken a "holier-than-thou" tone in their stories of Scott Amedure's death. It is possible the professional background of these reporters and columnists enabled them to view the talkshow host and producers as professionally careless in their attempts to achieve higher ratings via exploitative means.

At the routines and/or the individual level of influence, newspaper reporters often presented a one-sided story via the sources they used in their stories. Some stories, while seemingly objective, contained a position simply by the use of some sources and not others. It seems as if the "elite" newspapers relied on Thompson, the prosecutor, heavily because he provided a voice for their own point of view, or the one presumed to sell more newspapers. Thompson readily blamed the "Jenny Jones" show, Jenny Jones herself, and the talk-show producers for the murder. Numerous news stories quoted family members and friends of Schmitz in addition to psychologists and analysts hired by the defense team. Furthermore, "elite" journalists were able to work many expert and official sources into their stories by relying on murder experts and psychologists who provided a rationale for Schmitz's actions and in some cases even took the blame away from Schmitz and placed more blame on the talk show. Following Amedure's murder, several members of Congress also spoke publicly about the negative and violent content of television talk shows, and some even advocated removing the shows from television altogether. The 
inclusion of these sources in the news stories was certainly justifiable, yet few stories provided the depth and analysis that would represent alternative views. Initially, the "Jenny Jones" case did not receive the prominent news coverage of the other cases reviewed here. The murder wasn't considered newsworthy until the entertainment media were accused of committing the crime. The story seemed to illustrate the routines of "status conferral" and of pack journalism. As the story and its subjects became more prominent, it began to appear in more and more newspapers. Some newspapers devoted one story and several sidebars to the case for weeks and even months. Other newspapers ran stories for several days in a row, even though new information had not been uncovered or released. While this behavior may be standard practice in many newsrooms, it also illustrates the way news editors are often "forced" to allow more space for a story simply because the competition or national newspapers are running the story.

From an ideological or hegemonic standpoint, blaming the "Jenny Jones" show and its producers meant the "cause" for the tragedy was easily pinpointed. American society could point its finger at the media, and then, in a figurative sense, rest comfortably with the thought that the villain was identified. As de Mooij (1998) suggests, American culture strives for a source of blame, an identifiable cause, and views tragic events as a consequence of blame-worthy factors. Blaming the media, in this case, helps maintain order because members of society do not have to fear becoming victims themselves once the media have 
been isolated as the villain. The underlying text of the press coverage is that ordinary citizens do not have to fear for their safety unless they appear on a talk show themselves, rather than suggesting homophobia and hate are all too common in society. This well publicized case may have temporarily heightened the fear of members of society. With the elevated fear, they searched for a culprit, and once the talk shows were identified as the "cause," the fear subsided, and members of society, as well as those in the "elite" media, were able to feel more secure about their social world.

It seemed much easier to blame the products of popular culture when the finger-pointers could step back and draw a clear distinction between themselves and those they were blaming for the tragedy. By making daytime television seem sleazy, trashy and outlandish, the "elite" media improved their own image by comparison. However, the oversight seems to be that these same "elite" media were pulling similar stunts to draw in larger audiences themselves.

\section{Case III: Columbine High School Shootings}

On April 20, 1999, just before lunchtime, 18-year-old Eric Harris and 17year-old Dylan Klebold, armed with guns and homemade bombs, opened fire on their classmates at Columbine High School in Littleton, Colorado. The siege lasted over four hours and ended with fifteen dead, including the two gunmen, and several others wounded. It was the bloodiest school shooting in the history of the United States and was carried out with well-orchestrated and disturbingly cold and calculated precision - as well as visible glee on the part of the gunmen. 
The series of events and its aftermath left many to grapple with the difficult question of what had gone so terribly wrong that two young men would wreak such awful havoc on their peers.

This case study attempts to illustrate how the print news media covered this tragedy, with an emphasis on how journalists dealt with the task of addressing the issue of why the shooting occurred. In the course of investigating and discussing possible entities at fault, the news media quickly came to focus on popular-culture and entertainment-media products as causal contributors to the massacre at Columbine High. Extensive quotes drawn from major newspapers around the world (searched via Lexis-Nexis) illustrate and also place into context the tendency of the news media to point the finger of blame at popular culture following this tragic event.

Just the Facts

The very first accounts in the news media of the school shooting in Littleton, Colorado, followed traditional journalistic ideals of reporting on who, what, where, when, and how. The first day of coverage was a veritable media frenzy, with blow-by-blow accounts broadcast live across the United States on the major radio and broadcast television networks and extensive coverage of gory details on cable news networks. News that day featured terrified testimonials from students. Expressions of immense relief were broadcast as parents were united with their children. But above all, the view of a bloodied 
student escaping from a second-story window was perhaps the most memorable image, because of both its profundity and the number of times it was shown.

Quotes from print news media on April 20, 1999, document the tragic and frightening sequence of events and reflect the journalistic tradition of conveying the particulars (who, what, when, where and how) of the event. The first newspaper articles on the topic came out before all the facts were known and thus included attempts to find out what exactly was happening inside the school, reporting the harrowing estimations of how many were killed, how many wounded. From The Denver Rocky Mountain News, reporters Mike Anton, Manny Gonzalez, Kevin Vaughan, Charley Able, and Lou Kilzer, on April 20, 1999:

At least 21 people were injured today when two or three gunmen dressed in black overcoats and masks opened fire inside Columbine High School in Littleton. Witnesses said the gunmen, reportedly students, appeared to fire randomly and set off explosives, possibly pipe bombs, laughing as they went.

From The Denver Rocky Mountain News, reporter Mike Anton, on April 20, 1999: Authorities said some victims were still inside the school as of 2:15 p.m. About 30 students were reported hiding in the choir room.... Seconds after the shooting began, hundreds of students and teachers poured out of the school while others sought refuge inside, hiding under desks and locking themselves in bathrooms.... Said another student "We were all 
under the table and the girl across the table from me was shot in the head right there."

A finger pointing of sorts occurred on this day, but served to merely answer the most pressing question at hand: who was responsible for this tragedy? Early blame was narrowly focused on those quickly identified as the gunmen, Eric Harris and Dylan Klebold. News stories traced the steps of the siege, its consequences, and its perpetrators.

\section{Popular-Culture Culpability}

The next day, however, on April 21, 1999, the facts had been largely gathered and disseminated. News coverage would now be dominated by placing blame and assigning responsibility to various people, institutions, and entities. Exceptions to the blame-laying patterns that prevailed in the aftermath of the shooting were stories about vigils and grieving processes, connections made in communities around the country with those involved, and decisions to cancel sporting and other events in light of the tragedy. Most other stories appearing for more than a month later attempted not to repeat the who, what, where, when and how issues, but rather tackled the far more complex issue of why.

Instances of popular culture being blamed came quickly, on the day of the tragedy to help fill the broad expanse of time that cable news networks devoted to coverage, and in the days immediately following in print. The tradition of many news sources picking up the same angle or the same threads of the story was also readily apparent. Wire reports cropped up in newspapers across the 
nation, and the same shocking footage became less and less troubling as American television news viewers were exposed to it again and again. Once popular-culture products were introduced as culprits in early coverage, journalists across the world made a similar connection. Those who pointed the finger of blame at media and popular-culture products in newspaper coverage largely fell into three categories: students at Columbine and other area schools, experts - typically professors, counselors, attorneys, and police officers - and reporters and newspaper editorial staff writers themselves.

Many popular-culture products were implicated as causal contributors to Harris and Klebold's violence. Movies (especially The Matrix), television, video games, the Internet, and recorded music were all scrutinized as antisocial influences on the gunmen. In fact, though there is plenty of precedent for a single film or book, for instance, inspiring real-life antisocial behavior, the Columbine shooting stands out as the one historical incident in which so many different popular-culture products were seen as responsible in so many different ways. From The Atlanta Journal Constitution, reporter Mike Williams, on April 22, 1999: According to their friends, Harris, 18, and Klebold, 17, were part of a loose-knit group called the 'Trenchcoat Mafia' and often dressed in black, favoring leather and the long coats that have been featured in many violence-filled Hollywood movies. The boys played violent computer games for hours, friends said.... Harris set up an Internet home page that 
spouted Nazi ideology and condoned violence. The shootings came on the $110^{\text {th }}$ anniversary of Hitler's birthday.

From The Daily Telegraph (London), reporter John Hiscock, on April 22, 1999:

The two laughing teenagers who shot and bombed their way though the halls of Columbine High School were members of a Gothic-style group known as the Trenchcoat Mafia. Students at Littleton, Colorado, yesterday described Dylan Klebold, 17, and Eric Harris, 18, as "satanic individuals" who talked about Nazis and were fans of the "shock rock" star Marilyn Manson.

From The New York Daily News, reporter Helen Kennedy, on April 21, 1999: A Web page attributed to one of the members contained crude sketches of demons along with juvenile nihilism like "Anything I don't like sucks." There were song lyrics, from a German underground band called KMFDM an acronym for Kein Mehrfeit Fur Die Mitleid (No pity for the majority) including "What I don't like I waste," "I am your apocalypse," and "Chaos panic/no resistance/detonations in the distance."

From The Daily Telegraph (London), reporter John Hiscock, on April 22, 1999:

The Trenchcoat Mafia was born about three years ago when about a dozen students at Columbine started wearing black and listening to German techno music. They often wore German slogans and swastikas on their clothes. Both were obsessed with the Internet - widely used by neo-Nazi 
groups - and computer games. Their favourites were Doom and Quakeviolent fantasies where the aim is to kill everything you meet.

From The Denver Post, reporters Susan Greene and Bill Briggs, on April 21, 1999:

“It appears you have a bunch of kids who've been into black metal music-Marilyn Manson-who basically have apocalyptic fantasies and (who operate under) a heavy code of neo-Nazism," said (Dr. Carl) Raschke (author of Painted Black, which explores violent youth culture). From The Denver Rocky Mountain News, reporter Robert Denerstein, on April 22, 1999:

In the enormously popular new movie The Matrix, Keanu Reeves wears a black duster and battles the forces of evil with two-fisted bursts of gunfire. He stages an attack on the conspiracy that has turned his life into a living hell. The movie already is being mentioned as a possible source of influence on the Trench Coat Mafia, two of whose members entered Columbine High School Tuesday carrying weapons and wearing long black coats. It's not the first time movies have been connected with reallife violence...

The above quotes demonstrate the wide variation in types of popularculture products blamed, as well as the unique combinations of those entities that were viewed as responsible. They also demonstrate other aspects of youth culture, including hairstyles, body art, and means of dress, that were indirectly implicated in the news coverage of the Columbine shootings. The entire nation 
was introduced to "gothic" culture in a manner that was at times valiant in its pursuit of value-neutral reportage. At other times "gothic" culture was implicated as a menacing desensitization to and even morbid fascination with death and dying that purportedly helped explain why Harris and Klebold acted with such utter disregard for human life.

The short amount of time it took to blame popular media and popular culture was partially explained by the relationship of the events that occurred in Littleton that day to other school shootings with young perpetrators in other areas of the country. It was an eerily familiar formula, and attempts at explanation linked Columbine to these other school shootings as sources and reporters struggled to make sense of the lot. In fact, one newspaper account used the media and popular culture to link the tragedy at Columbine to another recent high-profile student shooting. From The Ottawa Citizen, reporters Bob Harvey and Christopher Guly, on April 22, 1999:

Just last week, parents of three girls killed in 1997 in Paducah, Kentucky, sued the makers of another film, The Basketball Diaries, starring Leonardo DiCaprio. The Paducah killer, Michael Carneal, said his decision to open fire on a school prayer group was influenced by that film.

\section{Exonerating Popular Culture/Sharing the Blame}

Certainly the media and popular-culture products were not the only entities blamed for the Columbine tragedy, though they were among the most frequent targets. Other sources of blame included poor parenting, unsafe schools, 
uninformed school and police officials, teen cliques, feelings of ostracism, and, perhaps the most frequent additional target of criticism - the prevalence and accessibility of guns. Some of those who assigned blame in the Columbine shootings chose to focus on only one of these culprits, while others argued that these factors acted in concert to explain the tragedy that had occurred. Some took the position that other societal factors outweighed the role of popular culture in contributing to the tragedy. Others seemed to feel that these entities should share the responsibility. From The Los Angeles Times, reporter Josh Getlin, on April 22, 1999:

The shooting also brings up an old question. How much responsibility does the culture bear for images of violence and retribution, which fill movies, TV, video games, the Internet, recorded music and even the most elementary cartoons today? "We've seen a steady escalation of violence as entertainment, and it reaches people in disturbing ways," (Joyce) Appleby (American history professor) said. “Billions of people watch these pictures around the globe, but somewhere a handful of boys weren't horrified, they were fascinated."

From The Ottawa Citizen, reporters Bob Harvey and Christopher Guly, on April 22, 1999:

Those especially vulnerable to violent media messages are individuals like the two gunmen in the Denver suburb Tuesday - who are "separated away from the mainstream," said Mr. (Andrew) Osler (media professor at 
the University of Western Ontario), who researches media and violence at the university's Faculty of Information and Media Studies.

A few reporters and experts alike voiced concern that media and popularculture products were serving as scapegoats in the wake of Columbine, possibly masking other, ostensibly more important causal factors. Articles defending these entities, however, were in the minority and tended to occur in response to the preceding types of popular-culture accusations. From The Chicago Sun Times, reporter Richard Roeper, on April 22, 1999:

It's impossible - and unfair - to point to a band or a movie or a TV show and say "That was the cause," and then to turn to a slaughter and say, "This is the effect." If that's the way it worked, how can it be that hundreds of thousands of fans the world over have been exposed to the spine-thumping music of KMFDM without turning violent?

From The Los Angeles Times, reporter Josh Getlin, on April 22, 1999:

“The media influences people, but you don't march into a school armed with guns and grenades and kill 13 people overnight. It doesn't come from nowhere," he (Todd Boyd, an author and professor at the USC School of Cinema and Television) added.

From The Denver Rocky Mountain News editorial, on April 21, 1999:

What, many Americans wonder, is going on? We don't profess to know, yet surely part of the answer is a relatively simple phenomenon: unbalanced, resentful kids imitating the highly publicized actions of other 
unbalanced kids. Most other explanations - the influence of violent entertainment, for example, or too-easy access to guns-suffer from the weakness of having long predated the recent trend of gun-toting students invading their schools with guns.

Do news accounts merely blame the content of popular entertainment media without assessing the factors leading up to the creation and distribution of that content? The answer in this case appears to be yes. Noticeably absent in coverage of the Columbine school shootings was a larger, more macroscopic context for popular-culture blame. Newspaper articles that mentioned either those who produce the content many found objectionable or the audience for this content that ensures its presence, or even society at large, were noticeably rare.

Though many an allegation was made against popular-culture products for their role in this shooting, most blamers did not accuse the producers of these products but rather just the products themselves. This seems to suggest media and popular-culture content were perceived as a given in this case. Most accounts did not tend to acknowledge that there were people making decisions that dictate what types of content we see in entertainment media and popular culture. Though very rare, we will share the few exceptions in which producers of the objectionable content were blamed. From The Boston Globe, reporter John Ellis, on April 22, 1999:

The television networks, the major movie studios, record companies, video game software producers, print and other media are spending 
hundreds of millions of dollars every year to adapt children to this diet of violence and carnage. Once addicted, they'll want more of it, which can and will be provided at a slightly higher price.

From The London Independent, reporter David Aaronovitch, on April 22, 1999:

Film-makers who allow violence to seem cool and attractive should examine their consciences. And we should criticise them more.

Organisations like CNN, who offered "uninterrupted live coverage" of events at Columbine High School, should consider whether that isn't exactly what the avenging dweebs want.

Some news accounts were acutely aware of the blaming tendency and viewed it as a defense mechanism for coping with the tragedy, also noting that at the most fundamental level, there truly was no sufficient explanation for a tragedy of such magnitude. These atypical news articles drew the most macroscopic picture possible, speculating on broad problems at issue in society or simply conceding that an accurate and fair assessment of blame was impossible. From The Arizona Republic editorial, on April 21, 1999:

Whatever that elusive answer may be, it is no longer enough to simply wag our fingers at the usual suspects. This time, we can't allow ourselves to simply scowl at the National Rifle Association. Or at disintegrating families and bleak, cynical television that trivializes life. We can't simply rage at bloody video games.

From The Boston Globe, reporter John Ellis, on April 22, 1999: 
We have surrounded ourselves with violence. It is everywhere we turn. It is in our music. It is on our televisions. It is in our movies. It is on our video games. It is prominently featured in print media and on popular Web sites. If it bleeds it leads and it leads because it sells. Tuesday's massacre at Columbine High School in Littleton, Colo., was not an aberration. It was and is a fact of modern American life.

From the Denver Rocky Mountain News editorial, on April 21, 1999:

But as we said, we don't know what the explanation is and don't care to speculate right now. The moment is too solemn, the bloodletting too extensive for the mind to even grasp. For the time being, our thoughts remain focused solely on those who lives now will never be the same.

\section{$\underline{\text { Unique Elements }}$}

The role of popular culture in the Columbine school shooting is a rather complex phenomenon. In addition to the basic and pervasive tendency to blame popular-culture products (films, television, video games, recorded music), there were three additional sources of media-related blame in newspaper coverage. First, many questioned the role of the local news media - universally picked up by the national news media - during the tragedy, in that their actions may have jeopardized the safety of the students in the school. Others blamed the news media for being unnecessarily sensationalistic, insensitive to the trauma experienced by those involved, and inordinately intrusive into the lives of members of the community. (It is important to note that still others applauded 
the local news media for accurate and compassionate reporting, though those accounts are not reported here as they do not involve blame.) These quotes also demonstrate the way in which some news organizations differentiated themselves from others. From The Atlanta Journal Constitution, reporters Don Aucoin, Drew Jubera, on April 21, 1999:

In the heat of the moment, missteps occurred. At one point, the information was broadcast that one youth was trapped inside the schools' "choir room," a potentially risky step if the gunmen were watching TV inside the school.

From The Chicago Sun Times, reporter Phil Rosenthal, on April 21, 1999: From ground zero of the melee at Columbine High School in Littleton, Colo., a student hiding under a table with his cell phone called to alert others of his predicament. His call went not to his parents or police, as some did. It went to Denver's KUSA-TV, which broadcast his report live in Denver (and nationally via CNN, MSNBC and CNBC), oblivious to the fact the school had TVs in every classroom and that the inside information might be aiding the gun-toting assailants behind the siege.

From The Boston Herald, reporter Monica Collins, on April 22, 1999:

On television yesterday, it was a mop-up operation after Tuesday's horrendous live coverage of the massacre at Columbine High School in Littleton, Colo. Bigfoot network reporters arrived, interviewing shellshocked student survivors. Sobbing parents who awaited their children's 
corpses at a nearby elementary school were not spared from the intrusive lenses. Viewers still shudder at the memory of those macabre, unfiltered visions captured at the height of the evil event...

Second, many critics of the news media also speculated on the possibility of copycat instances following the very extensive coverage the news media gave the event. Critics mentioned the unwitting tendency of the news media to elevate the perpetrators to cult celebrity status, which may, in turn, encourage similar behaviors from young people elsewhere. One might expect newspaper reporters to omit such instances in which news media were implicated, albeit indirectly, out of self-interest. However, sources consulted for the stories often thrust this angle into the news discourse about the event. Furthermore, newspapers were able to protect their own interests by emphasizing local strategies to avoid hypercoverage that may lead to copycat phenomena. From The Atlanta Journal Constitution, reporter Phil Kloer, on April 21, 1999:

As the sheriff spoke to reporters, news helicopters circled overhead. He was immersed in a sea of reporters, their microphones all lined up in concentric circles, pointing inward. "We've had a lot of media attention of these kinds of situations," the sheriff said, "and you don't know how much that gives other people the idea to do it."

From The Boston Herald, reporter Monica Collins, on April 22, 1999:

Detective Sgt. Margot Hill, the Boston police media relations director who helped hammer out the pact (setting standards for the airing of live 
tragedies) with Boston broadcasters, says “There's no value in airing live. If you air live, you're ghouls and you'll probably create a copycat within a week. We've become a nation of voyeurs."

From The Columbus Dispatch, reporter not listed, on April 22, 1999:

"Media attention has given a star quality to such incidents," (Richard) Hazler (a professor in Counselor Education at Ohio University) said.

"Kids now have the thought in their minds that it is possible to bring guns into school and get revenge that way," he said..."That's why copycat issues are such a concern today."

Third, another subtopic of media-related blame involved Harris and Klebold reportedly learning how to make pipe bombs on the Internet. From The New York Daily News, reporter Kevin McCoy, on April 22, 1999:

A Colorado prosecutor confirmed the cybersearch yesterday as new details emerged about violent imagery and pipe bomb assembly instructions on a Web site linked to gunman Eric Harris. "The Internet is very involved in this case," Jefferson County District Attorney David Thomas said when asked whether Harris and Dylan Klebold used computer expertise to plot the rampage.

From The London Independent, reporter David Aaronovitch, on April 22, 1999: Ah yes, but Eric and Dylan also had home-made pipe bombs. Where did those come from? Almost certainly from the pages of the Internet, where Randy from Idaho, or the Urban Terrorist's homepage, will give any 
teenager all the information he needs to know to blow up his enemies...Perhaps they were rendered immune to the reality of what they were planning to do as a consequence of long, crepuscular hours spent at the keyboard, blasting punks and decapitating jerks to earn record scores. After a while, real flesh may become confused with pixellated gore and guts in the adolescent mind.

\section{Connections with Theory}

The quotes from the newspaper coverage of the Columbine tragedy demonstrate many of the theoretical foundations outlined earlier in this monograph. Just as Pauly (1992) and Eason (1992) discuss in essays about Rupert Murdoch and the news story "Jimmy's World," respectively, analysis of the press coverage of the Columbine school shootings reveals rather ingrained, idealized notions about the nature of journalism. Journalists reporting on Columbine seem to deem themselves above the fray, even when discussing the apparent mistakes made by fellow journalists in covering the story, such as being too intrusive or insensitive or having coverage that is so extensive it could inspire a copycat shooting. In fact, some of the stories - either through the comments of sources or the words of journalists themselves - suggest disdain on the part of "serious" journalists for their more sensationalistic or entertainment-oriented counterparts.

Rarely was a distinction between "serious" journalism and more "frivolous" and presumably "harmful" entertainment media content made explicitly by a reporter in the story. Rather, the distinction was made implicitly in 
the tone of the stories, in the words and phrases chosen, and in the angles pursued in the telling of the story. The distinction that we argue is made here is similar to the one discussed by Bird (1992) in her analysis of tabloid newspapers and their relationship to "serious" journalism. In the case of Columbine, the distinction may, in fact, be easier for newspaper reporters to argue because the medium is often different, with newspapers or print journalism seen as "serious," informative, and helpful, and video games, recorded music, television, and movies seen as more "frivolous" and "harmful."

The same types of assumptions that Jensen (1990) argues underlie major strains of media criticism are apparent here. There is a sense of protectionism that borders on elitism on the part of those who criticized popular media in major newspaper coverage of the Columbine shootings, with the notion that the newspapers provide what is good for the public, and entertainment media provide what is bad. The newspaper's role is one of savior. By pointing out the evils of the popular media that Dylan Klebold and Eric Harris enjoyed, newspaper coverage can help save other impressionable youth or raise a warning flag for their parents.

The newspaper coverage of the Columbine school shootings can also be examined in terms of Shoemaker and Reese's (1996) levels of influence on media content. On the individual level, for instance, the tone of the coverage suggests that the journalists may have shared the sadness and outrage of the American public and were thus inclined to point the finger of blame as a way of coping 
with and trying to make sense of the tragedy. In fact, the immediate deaths of Klebold and Harris served to remove them as a target for continuing feelings of grief and anger. Assigning responsibility to an ongoing social institution such as the popular media provides both reporters and their readers with an enduring target at which they can vent their anger.

The individual reporters and their editors may also have chosen this angle because it corresponds with their own personal values or opinions regarding popular culture and media influence. The quotes that imply disapproval or the ones that adopt a moralistic tone would support this as one factor shaping coverage. Also on the individual level, reporters and editors at the newspapers whose coverage was examined may have felt a "holier than thou" attitude toward entertainment-oriented popular media. This influence bridges the theoretical structure of Shoemaker and Reese (1996) with that of Jensen (1990), Bird (1992), Eason (1992), and Pauly (1992).

On the media routines level, the routines regarding the selection and use of sources as well as the traditional emphasis on localism were apparent in coverage. For example, schoolmates and area residents were often called upon for first-hand accounts of possible popular-culture blame, and experts such as police officers or college professors were often utilized for verification. The coverage also evolved from reporting "who, what, where, when and how" to also including "why," the latter leading to the popular-culture blame explored here. Finally, the routine of providing simplified, uncomplicated explanations for 
events was followed in some of the coverage of the Columbine shootings that advanced one particular or more compelling explanation for the tragedy (often popular culture) rather than discussing multiple and complex factors.

In either the organizational or the extramedia level as defined by Shoemaker and Reese (1996), ownership issues and the chain of command may have influenced coverage of the Columbine shootings. With such a broad range of media and popular-culture products implicated, a conflict of interest was possible because of growing cross-media ownership. A newspaper owned by the same company that owns a record label whose bands or types of music were criticized for their role in the shootings may have been disinclined to emphasize the possible effect of that music on the shooters because of pressure from the top. On the other hand, a newspaper relatively free of those direct connections with the popular media being implicated (or with holdings in competing media that would benefit from a possible boycott of the particular popular media criticized) may be more likely to point the finger of blame.

In the case of Columbine, it is possible that manufacturers and distributors of popular-culture products that advertise in newspapers would be displeased with coverage that implicates those video games, the Internet, television or movies in such a high-profile tragedy. For instance, the newspapers from which we have quoted may carry lucrative advertising inserts for retail outlets offering or even specializing in media-driven products (TV sets, DVD players, video game consoles). Perhaps popular-culture culpability would have been even more 
extensive or scathing if it weren't for this influence that may have trickled down from the owners and managers in the newspaper's organizational structure.

Also on the extramedia level, the sources used to cover the Columbine tragedy helped shape the content. The students of Columbine High School were quick to report the violent and nihilistic media and popular culture content that attracted Klebold and Harris, as is apparent in the quotes from coverage above. This early angle may well have helped define the story from that point on. Similarly, the efforts of other media organizations to establish the popular-media culpability angle, including the hometown Denver newspapers who had the earliest and most extensive coverage, may have set the tone that other media organizations followed.

Finally, influences found at the ideological level may have shaped coverage of the Columbine shootings, as well. For instance, in many of the quotes from newspaper coverage outlined above, occasional resistance to assign blame to producers of content is evident, as writers relied instead on accusations against media content itself as divorced from those who created it. This may have been, consciously or not, a defensive strategy on the part of the newspapers to deflect criticism from their possible role in creating "a culture of violence" by helping to obscure the connection between the decisions and approaches of creators of content from content itself. Also evident in the language used to implicate popular media are the lines of distinction implicitly drawn in coverage of the Columbine tragedy between the news media who covered the event and the 
entertainment media who were blamed. The emphasis was often on the blood, gore, and generally antisocial content of music lyrics, video games, and movies, and the apparently disturbing notion that this is what is used to entertain young people in our society. Thus, responsibility was placed firmly at the feet of media who are merely entertaining the masses rather than the news media who are providing a public service by informing them. In the case of Columbine, there exists an underlying assumption that something is dreadfully wrong with the people who tune in to violent media fare and that the news media are trying to save them by pointing this out.

Also at the ideological level, blaming the media for the Columbine tragedy could help maintain comforting notions of social order and reassure the public of social stability. The discomfort that comes with leaving such a tragedy unexplained is evident in the very few editorials that expressed that they were mystified by the tragedy and admitted this created a disquieting sense of chaos. It is also evident in the majority of newspaper stories that did, indeed, offer the popular-culture culpability argument as an explanation. As de Mooij (1998) suggests, Americans are comforted by a sense of rationality and order, of things occurring for a reason. Advancing the popular-culture culpability attempts to bring rationality to the otherwise senseless nature of the tragedy, compounded because of the young age of the assailants and victims, the seemingly safe setting, and the apparent glee with which Klebold and Harris perpetrated their crimes. 


\section{Conclusions}

This study uses three high-profile cases to investigate conceptions regarding the moral consequences of popular media in contemporary society. In analyzing the discourse generated in news coverage of the three events, the theme of popular media's moral culpability was quite apparent. Whether it was for the car crash that claimed the life of Princess Diana, for the shooting that followed an apparently incendiary taping of the "Jenny Jones Show," or for the multiple-weapon assault enacted on Columbine High School, newspaper coverage included the assignment of blame to popular media and popularculture products for these tragedies.

Analysis of the news discourse surrounding these events points to a number of themes regarding cultural and social practices. First, we can examine views and perceptions of "the media" as having potentially different readings and carrying quite disparate moral connotations depending on one's perspective. Some conceptualize "the media" as a relatively homogeneous and powerful force in the contemporary social structure with only slight, if any, important differences based on news versus entertainment content. This view holds that each media outlet exists for the purpose of profit and seeks that profit by appealing to audiences of specific sizes or characteristics. Differences between news and entertainment are seen as minimal and shrinking, in a time in which "infotainment" abounds and the "news hole" in newspapers and on television is 
diminished by the amount of space or time allotted to weather, sports, and "light" features.

Yet, the discourse examined in newspaper coverage of these three events shows a very different view of "the media." Rather than assuming similarities between news and entertainment and rather than newspapers sharing a sense of responsibility for a "culture of violence" or sensationalism such as is criticized in these cases, "the media" is seen as a heterogeneous collection of very different types of organizations with very different functions. Implicit distinctions are drawn between those "serious" journalists whose function is to inform the public of important information related to their health and well being and those producers of popular media who flout this respected tradition and instead jeopardize public health by irresponsible practices and the transmission of potentially harmful content. The notion of irresponsible practices can be seen in the condemning tone in newspaper coverage that discusses the paparazzi in the case of Princess Diana's death and talk show producers and creators in the case of the "Jenny Jones Show" murder. The notion of harmful content is also an explicit element of the news discourse surrounding sensationalism, sex and violence in talk shows as related to the "Jenny Jones" murder and antisocial and violent themes in popular media as related to the Columbine shootings.

Thus, there are some parallels to the theoretical argument made by Jensen (1990). Jensen would argue that the view of the media described first above, as a homogeneous force, is an example of modern media criticism that may better be 
viewed as a criticism of modernity. Yet, she would presumably also object to the defensive strategies embarked upon by the newspapers whose coverage we examined because of their underlying assumptions regarding popular preferences and morality. These lines of distinction between "serious" and "popular" media comprise the second major theme revealed in this analysis. As mentioned in the case studies, the distinction between "us" and "them" was not always made explicitly in the news coverage of the events. However, in the pursuit of the popular-culture culpability angle, in the disapproving tone of sources turned to or in reporters' own words, and in the lack of connection established between the newspaper itself and the other forms of media criticized, the distinction appears as an underlying assumption.

This assumption is tenuous at best. As Bird (1992) and Pauly (1992) suggest, those who position themselves as "serious" journalists and those who are viewed as "tabloid" journalists (and even those who create and disseminate entertainment media content) have more similarities than differences in terms of practices and goals. Yet, even when the connection between the accuser (the newspaper) and the accused seems most obvious, as in the discussion of excessive news coverage paving the way for copycat crimes following Columbine, no elements of the discourse suggest similarity or recognize potential involvement on the part of the accuser. Rather, the newspapers reported from a presumed position above the fray, akin to an omniscient and impartial observer, who then adopts an interpretive role to further the public 
good by helping to cure social ills. This not only reveals a privileged position for "elite" journalists but also suggests an artificial, unrealistic isolation of the newspaper from surrounding society.

At the center of the issue of what makes a media professional "serious" or not is an assumption about the nature of the audience. The analysis of news discourse provided here shows further evidence of a protectionist, somewhat elitist view of audiences as being drawn, like moths to a flame, to content that is bad for them. Whether one blames the producers of such content or the audience members themselves for this assumed preference, the premise is the same: audience members must be encouraged to see the error of their ways in their enjoyment of or tolerance for violent, sexual, sensationalistic, and intrusive media content. Some of the quotes we have cited from newspaper coverage of these three events appear to adopt the position that deaths such as these are the price we pay for the moral decline evident in the popularity of certain types of media content. Others reveal a tone of warning for local communities to prevent similar tragedies from occurring or recurring. Still others call directly for greater governmental regulation, stricter parental control, and more responsibility on the part of the media industry. All such angles suggest a need for those wiser and more moral - in this case, presumably the "serious" journalists - to help save audience members from themselves.

Underlying the blame of popular media and culture in the media discourse examined in our study is the "serious" journalists' notion of audience 
members preferring what is "easier to digest" or more appealing (popular media and culture) rather than what is good for them. What is good for them, in the case of our study, is presumably more "elite" media and culture, including the reading of newspapers such as those that are blaming their more populist counterparts. By focusing on the aspect of each story that involves purportedly appealing qualities of the popular media criticized, "elite" newspapers can capitalize on those qualities (e.g., violence in the case of Columbine, sex in the case of "Jenny Jones") while implicitly drawing a distinction that separates them as more "tasteful."

Shoemaker and Reese's theory of influences on media content (1996) also provides insights about situated, particular practices of news professionals, constraints and traditions in news gathering, and the interplay of producers, content, and public. Of the five spheres of influence identified by Shoemaker and Reese, we would argue that media routines were among the most likely to have a direct and measurable impact on how these three events were covered in the news. Routines including news values, ideas of what makes a "good" story, and traditional practices and constraints of news reportage are also presumably the influences that would most likely be listed by journalists themselves if asked what factors affect how events are covered, because of their practicality and concrete nature. The other more microscopic spheres of influence are slightly less compelling in this context. For example, though many journalists would welcome a work environment in which their own preferences, opinions, and 
values could dictate coverage, few achieve this degree of autonomy and write articles that run unchanged by higher-ups in the organizational structure.

We believe the more macroscopic factors of extramedia influences and ideology also play a crucial role, but one which is less apparent and more insidious. It is this element of the Shoemaker and Reese (1996) theory that can be linked to the theoretical contributions of Jensen (1990), Bird (1992), Pauly (1992), and Eason (1992). Though these forces are not always obvious, we argue that the factors comprising them are among the most potent in shaping news content in general, and coverage of these events specifically. The influence of ideology encompasses cultural elements such as the cause-and-effect paradigm that de Mooij (1998) suggests is expected in American culture. This cultural norm is readily apparent in news-media discourse surrounding each of these three events, evident in the attempts to answer "why" the tragedies occurred in a simple and straightforward manner.

The ideological level also encompasses the issues of journalists (and others) holding rather unflattering perceptions of audience members and espousing a somewhat idealized role of the "serious" journalist as watchdog in contemporary society. In this scenario, there is a protectionism that borders on elitism. A key element interwoven throughout these theoretical foundations is hegemony. A revered and respected role reserved for "serious" journalists assures their position in society. Economics also play a crucial part. Newspapers tell stories in a certain way to sell copies in order to sell space to advertisers. 
Popular culture culpability, by its very populist nature, is a virtual guarantee of public interest. Yet, the public may be surprised to find the news discourse generated is one of shame, guilt, and danger associated with popular media.

We would like to caution our readers, however, about assumptions that underlie this research endeavor. Our aim here was not to blame the "serious" news media for, in turn, blaming more populist news and entertainment media because we feel that blame is not deserved. On the contrary (and perhaps contrary to the position Jensen would adopt), we do believe there are irresponsible practices and potentially harmful content in tabloid news and entertainment media that may have contributed - though certainly not as the sole culprit - to these three tragedies, and other events as well. Our purpose here was to examine how this blame took shape, to illuminate forces and factors that led to the pursuit of this blaming as a common angle, and to elucidate the implicit strategies to keep "serious" journalists above blame. It is this distinction that is made between accuser and culprit in the news coverage we examined, when the distance between the two is arguably quite small, that we suggest is the most interesting finding from our study. 


\section{$\underline{\text { References }}$}

Abt, V., \& Seesholtz, M. (1994). The shameless world of Phil, Sally and Oprah:

Television talk shows and the deconstructing of society. Journal of Popular Culture, 28, (1) 195-215.

American Academy of Pediatrics (1996). Impact of music lyrics and music videos on children and youth. Pediatrics, 98, 1219-1222.

Anderson, C.A. (1997). Effects of violent movies and trait hostility on hostile feelings and aggressive thoughts. Aggressive Behavior, 23, 161-179.

Anderson, C.A., \& Ford, C.M. (1986). Affect of the game player: Short-term effects of highly and mildly aggressive video games. Personality and Social Psychology Bulletin, 12, 390-402.

Anderson, K. (1993, October 11). Oprah and Jo-Jo the dog-faced boy. Time, 94.

Ballard, M.E., \& Lineberger, R. (1999). Video game violence and confederate gender: Effects on reward and punishment given by college males. Sex Roles: A Journal of Research, 41, 541-558.

Ballard, M.E., \& Wiest, J.R. (1996). Mortal Kombat: The effects of violent video game play on males' hostility and cardiovascular responding. Journal of Applied Social Psychology, 26, 717-730. 
Berkowitz, L. (1993). Aggression: Its causes, consequences, and control. Chapter 7 (pp. 199-239). New York: McGraw Hill.

Betsch, T., \& Dickenberger, D. (1993). Why do aggressive movies make people aggressive? An attempt to explain short-term effects of the depiction of violence on the observer. Aggressive Behavior, 19, 137-150.

Bird, S. E. (1992). For enquiring minds: A cultural study of supermarket tabloids. Knoxville: The University of Tennessee Press.

Bishop, R. (1999). From behind the walls: Boundary work by news organizations in their coverage of Princess Diana's death. Journal of Communication Inquiry, 23, (1) 90-112.

Black, S.L., \& Bevan, S. (1992). At the movies with Buss and Durkee: A natural experiment on film violence. Aggressive Behavior, 18, 37-46.

Boorstin, D.J. (1972). The image: A guide to pseudo-events in America. New York: Atheneum.

Brinson, S., \& Winn, E. (1997). Talk shows' representations of interpersonal conflicts. Journal of Broadcasting and Electronic Media, 41, (1) 25-39.

Charters, W.W. (1933). Motion pictures and youth: A summary. New York: Macmillan.

Clark, D.G., \& Blankenburg, W.S. (1972). Trends in violent content in selected mass media. In G. Comstock \& E. Rubinstein (Eds.), Television and social behavior: Vol. 1. Media content and control (pp. 188-243). Washington, DC: U.S. Government Printing Office. 
Comstock, G., \& Scharrer, E. (1999). Television: What's on, who's watching, and what it means. San Diego, CA: Academic Press.

Cooper, J., \& Mackie, D. (1986). Video games and aggression in children. Journal of Applied Social Psychology, 16, 726-744.

de Mooij, M. (1998). From global marketing and advertising: Understanding cultural paradoxes. Newbury Park, CA: Sage.

Dorfman, L., \& Woodruff, K. (1998). The roles of speakers in local television news stories on youth and violence. Journal of Popular Film and Television, 26, 80-86.

Dorfman, L., Woodruff, K., Chavez, V., \& Wallack, L. (1997). Youth and violence on local television news in California. The American Journal of Public Health, $87,1311-1317$.

Eason, D. (1992). On journalistic authority: The Janet Cooke scandal. In J. Carey (Ed.), Media, myths and narratives: Television and the press, pp. 205-227.

Eichholz, M. (1998, August). Thoughtful self-critique or journalistic cannibalism? International press coverage of Princess Diana's death. Paper presented at the annual meeting of the Association for Education in Journalism and Mass Communication, Baltimore, MD.

Ewen, S. (1976). Captains of consciousness: Advertising and the social roots of the consumer culture. New York: McGraw-Hill.

Greenberg, B.S., Sherry, J.L., Busselle, R.W., Hnilo, L.R., \& Smith, S.W. (1997). Daytime television talk shows: Guests, content and interactions. 
Journal of Broadcasting and Electronic Media, 41, 412-426.

Greenfield, P.M., Bruzzone, L., Koyamatsu, K., Satulof, W., Nixon, K., Brodie, M., \& Kingsdale, D. (1987). What is rock music doing to the minds of our youth? A first experimental look at the effects of rock music lyrics and music videos. Journal of Early Adolescence, 7, 315-329.

Irwin, A.R., \& Gross, A.M. (1995). Cognitive tempo, violent video games, and aggressive behavior in young boys. Journal of Family Violence, 10, 337350.

Jensen, J. (1990). Redeeming modernity: Contradictions in media criticism. Newbury Park, CA: Sage.

Kunkel, D. (1994). The news media's picture of children. Children Now, Los Angeles, CA.

Long, R. (1999, July 26). Hollywood, Littleton, and us. National Review, 44.

Macdonald, D. (1962). Against the American grain. New York: Random House.

Oliver, C. (1995, April). The sleazing of America. Reason, 142-144.

Pauly, J. J. (1992). Rupert Murdoch and the demonology of professional journalism. In J. Carey (Ed.), Media, myths and narratives: Television and the press, pp. 246-261.

Peck, J. (1995). TV talk shows as a therapeutic discourse: The ideological labor of the televised talking cure. Communication Theory, 5, (1) 58-81. 
Peterson, R.C., \& Thurstone, L.L. (1933). Motion pictures and the social attitudes of children. New York: Macmillan.

Postman, N. (1985). Amusing ourselves to death: Public discourse in the age of show business. New York: Viking.

Potter, W.J. (1999). On media violence. Thousand Oaks, CA: Sage.

Priest, P.J., \& Dominick, J. R. (1994). Pulp pulpits: Self-disclosure on “Donahue." Journal of Communication, 44, (4) 74-97.

Real, M. (2000, June). Mourning Diana: Religious functions of media rituals. Paper presented at the annual meeting of the International Communication Association, Acapulco, Mexico.

Schutte, N.S., Malouff, J.M., Post-Gordon, J.C., \& Rodasta, A.L. (1988). Effects of playing video games on children's aggressive and other behaviors. Journal of Applied Social Psychology, 18, 454-460.

Sheinfeld, L.P. (1986, May-June). Ratings: The big chill. Film Comment, 22, 3.

Shoemaker, P., and Reese, S. (1996). Mediating the message: Theories of influences on mass media content. White Plains, NY: Longman Publishers USA.

Silvern, S.B., \& Williamson, P.A. (1987). The effects of video game play on young children's aggressive, fantasy, and prosocial behavior. Journal of Applied Developmental Psychology, 8, 453-462.

St. Lawrence, J.S., \& Joyner, D.S. (1991). The effects of sexually violent rock music on males' acceptance of violence against women. Psychology of Women Quarterly, 15, 49-64. 
Surette, R. (1997). Media, crime, and criminal justice: Images and realities. New York: Wadsworth.

Tavener, J. (2000). Media, morality, and madness: The case against sleaze TV. Critical Studies in Media Communication, 17, 1, pp. 63-85.

Wass, H., Miller, M.D., \& Redditt, C.A. (1991). Adolescents and destructive themes in rock music: A follow-up. Omega, 23, 199-207. 